\title{
DETERMINAN FRAUD PREVENTION PADA PEMERINTAHAN DESA DI KABUPATEN BANJAR
}

\section{DETERMINANT OF FRAUD PREVENTION IN VILLAGE GOVERNMENT IN BANJAR REGENCY}

\author{
Elva Rahmawati ${ }^{1)}$ Sarwani $^{2)} \operatorname{Rasidah}^{3)}$ Mellani Yuliastina ${ }^{4)}$ \\ Magister Akuntansi FEB Universitas Lambung Mangkurat ${ }^{1,2,3)}$ \\ STIE Nasional Banjarmasin ${ }^{4)}$
}

\begin{abstract}
This study aims to examine the influence of variable competence of personnel, internal control systems, control of conflict of interest, morality, accountability, law enforcement and suitability of compensation for prevention of fraud in village financial management. Prevention of fraud becomes very important as an effort to create a climate of transparency and freedom from fraud in the management of village finances in order to realize good governance. This study uses the questionnaire survey, the number of samples used by 164 villages in Banjar Regency, where each village was taken 3 village fund managers, namely the village head, village secretary and financial staff, totaling 492 people. Analysis of data using multiple linear regression. The results showed that the competence of personnel, internal control systems, conflict of interest control, morality, accountability, and suitability of compensation significant affect on the fraud prevention in village financial management. Meanwhile law enforcement does not have a significant effect on the fraud prevention in village financial management.
\end{abstract}

Keyword: Fraud Prevemtion, Village Fund, Fraud

\begin{abstract}
ABSTRAK
Tujuan penelitian ini untuk menguji pengaruh variabel kompetensi aparatur, sistem pengendalian internal, pengendalian conflict of interest, moralitas, akuntabilitas, penegakan hukum dan kesesuaian kompensasi terhadap pencegahan fraud dalam pengelolaan keuangan desa. Pencegahan kecurangan menjadi hal yang sangat penting sebagai upaya untuk menciptakan iklim transparansi dan bebas dari tindak kecurangan dalam pengelolaan keuangan desa demi terwujudnya tata kelola pemerintahan yang baik. Penelitian ini dilakukan dengan menyebarkan kuesioner, jumlah sampel yang digunakan 164 Desa di Kabupaten Banjar, dimana masing-masing desa diambil 3 orang pengelola dana desa yaitu kepala desa, sekretaris desa dan kaur keuangan, sehingga berjumlah 492 orang. Analisis Data menggunakan regresi linear berganda. Hasil penelitian menunjukkan bahwa kompetensi aparatur, sistem pengendalian internal, pengendalian conflict of interest, moralitas, akuntabilitas, dan kesesuaian kompensasi berpengaruh signifikan terhadap pencegahan fraud dalam pengelolaan keuangan desa. Sementara itu penegakan hukum tidak berpengaruh signifikan terhadap pencegahan fraud dalam pengelolaan keuangan desa.
\end{abstract}

Kata Kunci: Pencegahan Fraud, Dana Desa, Fraud

Corresponding author: erahmawati.maksi.ulm@gmail.com

Email : erahmawati.maksi.ulm@gmail.com ${ }^{1)}$, sarwanifekon123@gmail.com ${ }^{3)}$, acie_akt@yahoo.co.id ${ }^{4)}$ myuliastina@gmail.com

DOI : https://doi.org/10.33369/j.akuntansi.9.3.129-152 


\section{PENDAHULUAN}

Pemerintah Indonesia mulai mewujudkan pembangunan daerah khususnya untuk membenahi dan memajukan ekonomi desa dengan dikeluarkannya Undang-Undang No 6 Tahun 2014 tentang pemerintahan desa. Undang-Undang ini mengamanatkan bahwa desa sekarang sudah bisa aktif dalam pembangunan guna mencapai kesejahteraan dan kemakmuran serta menjadi desa yang mandiri (Undang Undang Republik Indonesia No 6 Tahun 2014 Tentang Desa, 2014). Pengelolaan keuangan desa pada sektor pemerintahan bisa saja terjadi potensi adanya fraud, yang seharusnya berpedoman pada prinsip-prinsip berikut:(1) Keterbukaan dalam penyusunan anggaran melalui musyawarah desa untuk menyusun APBDes, serta dilaksanakan dan dievaluasi secara transparan dan berbagai unsur masyarakat terlibat; (2) Pertanggungjawaban secara administrasi, teknis, dan hukum dari seluruh kegiatan dana desa; (3) Masyarakat mendapatkan informasi tentang keuangan desa secara terbuka; (4) Hemat, terarah, dan terkendali merupakan prinsip penyusunan anggaran dan pengelolaan keuangan(Oktaviani et al., 2017).

Problem mendasar yang utama dari korupsi di desa menurut Indonesia Corruption Watch (ICW), menyangkut pengelolaan anggaran desa yang besar namun tidak diiringi prinsip keterbukaan dan partisipasi masyarakat desa (Indonesia Corruption Watch, 2018). Pemilu serentak tahun 2019 menyisakan kekhawatiran terhadap fenomena korupsi selama tiga tahun terakhir di desa, mengingat kepala desa memiliki kewenangan dalam pemenangan calon kepala daerah tertentu. Berbagai modus korupsi di desa, diantaranya budget misuse 51 perkara, embezzlement 32 perkara, fictitious report 17 perkara, fictitious activities or projects 15 perkara, dan inflated the budget 14 perkara(Indonesia Corruption Watch, 2018), seperti dalam gambar 1 berikut:

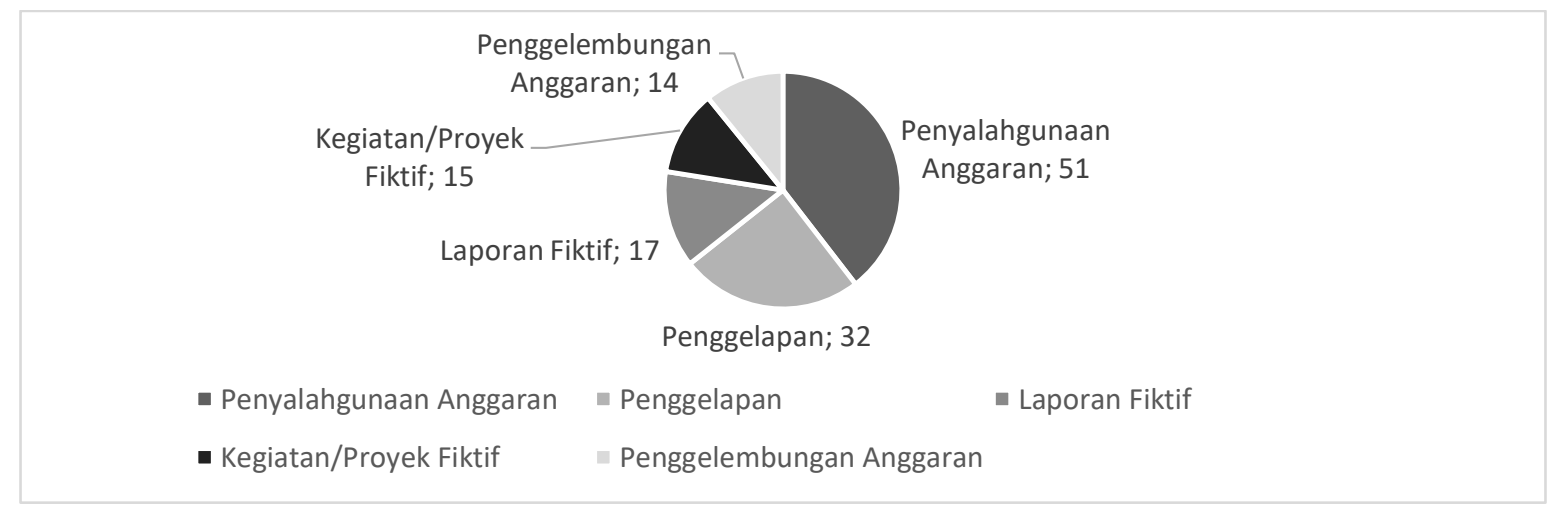

\section{Gambar 1 \\ Diagram Modus Korupsi Dana Desa \\ Sumber: ICW (Outlook Dana Desa 2018)}

Permasalahan yang terjadi terkait penyelewengan dana desa di Kabupaten Banjar diantaranya yang terpublikasi di media dan inspection report dari Badan Pemeriksa Keuangan (LHP BPK) tahun 2018 (Badan Pemeriksa Keuangan, 2018), disajikan dalam bentuk tabel 1 berikut:

Tabel 1.

Daftar Kasus Penyelewengan Dana Desa di Kabupaten Banjar

\begin{tabular}{|c|c|c|c|}
\hline No & Keterangan Kasus & Kerugian Negara & Tindak Lanjut \\
\hline 1 & $\begin{array}{l}\text { Kasus ruas jalan Desa Kahelaan yang } \\
\text { dilaporkan masyarakat kondisinya }\end{array}$ & Rp.173.433.567,00 & $\begin{array}{l}\text { Polres Banjar melimpahkan berkas } \\
\text { Penyimpangan Dana Desa Kahelaan }\end{array}$ \\
\hline
\end{tabular}




\begin{tabular}{|c|c|c|c|}
\hline No & Keterangan Kasus & Kerugian Negara & Tindak Lanjut \\
\hline & $\begin{array}{l}\text { diduga fisiknya tidak sesuai dengan } \\
\text { anggaran desa yang mencapai Rp.600 } \\
\text { juta, (Tribunnews.com, 2018) }\end{array}$ & & ke Kejaksaan, \\
\hline 2 & $\begin{array}{l}\text { Kasus Pengelakan Pajak di beberapa } \\
\text { desa di Kabupaten Banjar mulai } \\
\text { tahun 2015-2018(Badan Pemeriksa } \\
\text { Keuangan, 2018). }\end{array}$ & Rp 264.827.918,11 & 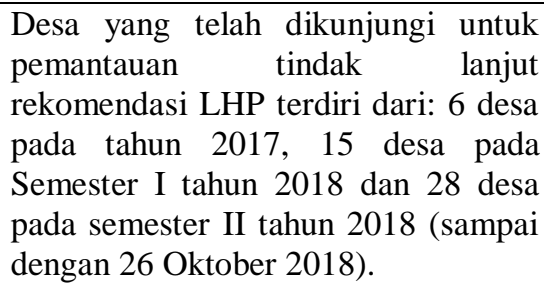 \\
\hline 3 & $\begin{array}{l}\text { Penggunaan } \text { SILPA dari beberapa } \\
\text { desa di Kabupaten Banjar dari tahun } \\
2015 \text { s.d } 2017 \text { yang belum } \\
\text { dilaporkan(Badan } \\
\text { Keuangan, 2018). }\end{array}$ & $\mathrm{Rp} 440.194 .343,63$ & $\begin{array}{l}\text { Penyelesaian tindak lanjut mencapai } \\
50 \% \text {, }\end{array}$ \\
\hline 4 & $\begin{array}{l}\text { Realisasi Penggunaan Dana Desa } \\
\text { tahun } 2018 \text { dari beberapa desa di } \\
\text { Kabupaten Banjar tidak ada bukti } \\
\text { pertanggungjawaban(Badan } \\
\text { Pemeriksa Keuangan, 2018). }\end{array}$ & Rp2.046.407.954,61 & $\begin{array}{l}\text { Penyelesaian tindak lanjut mencapai } \\
50 \% \text {, }\end{array}$ \\
\hline
\end{tabular}

Sumber : LHP BPK, Media, Data diolah (2018)

Menurut Fraud Diamond Theory, individu melakukan fraud dikarenakan empat elemen yaitu: 1)Tekanan (Pressure) adalah tekanan financial maupun non financial dari seseorang maupun tekanan dari perusahaan merupakan motivasi dari individu atau karyawan untuk bertindak fraud 2) Peluang (Opportunity) adalah kelemahan dari efektifitas pengendalian dapat memberi kesempatan terjadinya fraud 3) Rasionalisasi (Rationalization) adalah rendahnya penalaran moral dan integritas pribadi serta etika lokal sehingga membolehkan fraud terjadi 4) Capability (kemampuan), memiliki karakter dan kapasitas yang diperlukan untuk menjadi orang yang tepat untuk melakukan fraud (Tuanakotta, 2010).

Fakta fraud yang ditemukan adalah hasil dari kecurangan yang dilaporkan pada penegak hukum, sehingga sedikit kecurangan yang dapat terungkap dari yang sesungguhnya terjadi, hal ini karena fraud merupakan skandal yang harus ditutupi dari pihak lain dan kerugian karena fraud tidaklah kecil. Sektor keuangan desa tidak ada yang bebas dari fraud, sebaik apapun penerapan strategi anti fraud, permasalahan kembali kepada manusia yang menjalankannya karena tidak semua orang tulus dan berkarakter baik. Fraud pada sektor keuangan desa adalah seperti penyakit, lebih baik mencegah dari pada mengobati, Oleh karena itu upaya utama seharusnya adalah pada pencegahannya (Priantara, 2013).

Beberapa faktor yang di duga dapat mencegah terjadinya fraud di Pemerintahan Desa, diantaranya penelitian Atmadja dan Saputra (2017) tentang Dana Desa di kabupaten Buleleng menunjukkan bahwa kompetensi aparatur yang memadai, sistem pengendalian internal yang bagus didukung oleh moralitas aparatur yang baik, maka segala jenis kecurangan pengelolaan dana desa dapat dicegah (Atmadja et al., 2017). Selain moralitas yang baik, akuntabilitas dalam pengelolaan keuangan desa sangat diperlukan untuk mempertanggungjawabkan pengelolaan keuangan dan pelaksanaan pemerintahan desa secara akuntabel dan transparan (Mardiasmo, 2018). Praktik akuntabilitas harus didukung oleh pengendalian conflict of interest dalam mengelola keuangan desa. Karena adanya berbagai konflik kepentingan dari kepala desa menyebabkan munculnya potensi fraud atau kecurangan dalam mengelola keuangan desa. Sehingga dengan pengendalian konflik akan dapat mencegah terjadinya kecurangan dalam pengelolaan keuangan desa (oktaviani et al, 2017).

Hal yang tidak kalah penting dalam mencegah kecurangan adalah penegakan hukum dimana dengan kesadaran dalam menaati peraturan dengan baik dapat meminimalisir adanya 
kecurangan (wulandari,2016), serta pemberian kompensasi yang sesuai dengan pekerjaan pegawai dapat membuat pegawai merasa tercukupi sehingga akan meningkatkan kinerja pegawai dan mencegah tindakan kecurangan (fraud) (Chandra \& Ikhsan, 2015).

Seseorang yang merasa kurang cukup terhadap imbalan yang diperoleh dari pekerjaan yang mereka kerjakan juga merupakan motivasi individu untuk melakukan kecurangan (fraud). Kompensasi yang layak berakibat pada kepuasan terhadap keperluan hidup, sehingga tindakan kecurangan (fraud) dapat diminimalisir (Chandra \& Ikhsan, 2015). Pemberian kompensasi yang memadai dapat mempengaruhi tindakan dan kinerja pegawai sehingga dapat mengurangi tindakan kecurangan (fraud) (Adi et al., 2016). Hasil yang berbeda dikemukakan oleh penelitian Adinda \& Ikhsan (2015) yang menyatakan bahwa pemberian kompensasi tidak dapat mengurangi tindakan kecurangan(Adinda and Ikhsan 2015).

Berdasarkan gap hasil penelitian serta fenomena kasus fraud keuangan desa yang terjadi di Kabupaten banjar, memotivasi penelitian ini dengan mengidentifikasi faktor-faktor yang dapat mengupayakan pencegahan kecurangan yaitu dengan meningkatkan kompetensi aparatur, memperbaiki sistem dan mekanisme pengawasan dana desa, mengoptimalkan monitoring tindak lanjut hasil pemeriksaan di desa, reformasi birokrasi terutama di sektor penegakan hukum dan peradilan. Urgensi penelitian ini mengingat semakin maraknya penyalahgunaan wewenang oleh kepala desa dalam hal kurangnya transparansi dalam penunjukan tim yang membantu PPKD untuk melaksanakan kegiatan pengadaan barang/jasa dari unsur masyarakat, hal ini berkenaan dengan regulasi yang masih abu-abu terkait dengan pencegahan fraud seperti permendagri 20 tahun 2018 tentang PPKD yang belum jelas, selain itu pemerintahan desa belum memiliki komitmen penuh untuk melakukan tindak lanjut terhadap hasil audit. Untuk itu perlu diidentifikasi faktor-faktor apa saja yang berpengaruh untuk mencegah kecurangan pengelolaan keuangan desa.

\section{KERANGKA TEORITIS DAN HIPOTESIS}

\section{Agency Theory}

Penyalahgunaan dana desa akan mengakibatkan tidak akuratnya pelaporan keuangan desa sebagai bentuk pertanggungjawaban pemerintah desa. Teori keagenan oleh Jensen \& Meckling (1976) memfungsikan bahwa laporan keuangan yang dibuat diharapkan dapat meminimalkan konflik diantara pihak-pihak yang berkepentingan, seringkali individu akan bertindak sesuai dengan kepentingan mereka. Bentuk hubungan keagenan dalam pemerintahan daerah berupa pendelegasian wewenang kepada pemerintah daerah sebagai agent dalam melaksanakan pemerintahan serta pelayanan kepada masyarakat sebagai principal secara efektif, transparan, terpadu dan efisien (Yamin, Ridha, 2015).

Teori keagenan Jensen \& Meckling (1976) dimana permasalahan yang sering muncul dalam hubungan keagenan yaitu antara principal dan agent mempunyai tujuan dan kepentingan yang tidak sama, selain itu apa yang dilakukan agent terkadang sulit ditelusuri oleh principal. Faktor moralitas juga menentukan kecenderungan kecurangan manajemen (Wilopo, 2006). Eisenhardt (1989) teori agensi dijelaskan dalam 3 karakter individu yang fundamental yaitu: pertama, individu mengutamakan kepentingan pribadi (self interest); kedua, seseorang berfikir pendek untuk masa depan (bounded rationality); dan ketiga. seseorang cenderung menolak resiko (risk averse).

Pengelolan Dana Desa melahirkan hubungan principal dan agent, dimana pemerintah desa dipercayakaan untuk mengelola dana desa sebagai agent dan masyarakat desa serta pemerintah pusat sebagai principal. Hal tersebut menuntut transparansi dalam pengelolaannya sehingga tidak terjadi penyalahgunaan dan fraud. 


\section{The Fraud Diamond Theory}

Menurut Wolfe \& Dana (2004) untuk peningkatan upaya pencegahan dan deteksi fraud dengan fraud diamond theory yang merupakan penyempurnaan dari fraud triangle yang dikemukakan oleh Cressey (1953). Selain rationalization, pressure, dan opportunity, yaitu dengan mempertimbangkan elemen keempat individual's capability (kemampuan individual). Individual's capability adalah merupakan kemampuan seseorang untuk memahami kelemahan pengendalian internal, mempunyai posisi dan punya kewenangan, serta mampu meyakinkan orang lain dengan kebohongan yang dengan semua itu digunakan untuk kecurangan (Priantara, 2013).

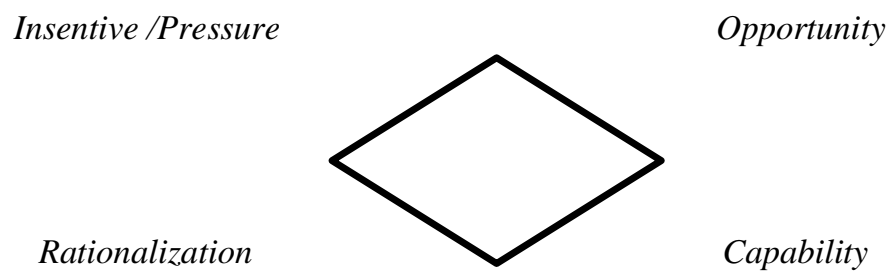

Gambar 2. Fraud Diamond Theory

Sumber: David T Wolfe dan Dana R. Hermanson, 2018

Penelitian ini memproksikan variabel independen berdasarkan teori Fraud Diamond, dimana pressure/insentive diproksikan dengan adanya pengaruh kesesuaian kompensasi dan akuntabilitas, opportunity diproksikan dengan adanya variabel sistem pengendalian internal, kompetensi aparatur dan penegakan hukum, rationalization diproksikan dengan variabel moralitas, sedangkan capability diproksikan dengan variabel pengendalian conflict of interest.

\section{Kompetensi Aparatur}

Semakin tinggi kompetensi yang dimiliki aparatur pemerintah, berdampak pada meningkatnya kualitas laporan keuangan pemerintah daerah dan dapat mencegah terjadinya kecurangan (fraud). Menurut fraud diamond theory, dimana opportunity (peluang) adalah kelemahan dalam sistem yang dapat dimanfaatkan berbuat fraud, baik kelemahan pengendalian internalnya maupun kelemahan dalam hal kompetensi aparaturnya. Penelitian yang mendukung pernyataan tersebut adalah Atmadja dan Saputra (2017), Inayatillah dan Awaluddin (2015) dan Saputra dan Pradnyanitasari ( 2019), Siahaya, Asnawi, \& K. Allo Layuk (2015). Hipotesis pertama yang diajukan dalam penelitian ini adalah:

$\mathrm{H}_{1}$ : Kompetensi aparatur berpengaruh terhadap pencegahan fraud dalam pengelolaan keuangan desa.

\section{Sistem Pengendalian Internal}

Tuanakotta (2010) menyatakan bahwa langkah awal dalam pencegahan fraud dilakukan dengan efektifnya pengendalian internal. Pencegahan fraud secara umum merupakan tujuan utama organisasi dapat terwujud secara maksimal dengan kepastian bahwa pimpinan organisasi dan seluruh unsur lainnya sudah menjalankan kebijakan sesuai prosedur dan ketetapan hukum (Tuanakotta, 2010). Tujuan sistem pengendalian internal adalah untuk keamanan aset, memperoleh laporan yang akuntabel, serta karyawan mematuhi aturan hukum yang ada.

Jika dikaitkan dengan teori fraud diamond, dimana opportunity (peluang) adalah kelemahan dalam sistem yang dapat dimanfaatkan berbuat fraud, yaitu kelemahan pengendalian internalnya. Melalui peningkatan penerapan sistem pengendalian internal, berdampak pada meningkatnya kualitas laporan keuangan pemerintah daerah dan dapat mencegah terjadinya kecurangan (fraud). Senada dengan hal diatas adalah penelitian Mulia, 
Febrianto, \& Kartika (2017), Donelson, Ege, \& McInnis (2017), Zulaikha \& Hadiprajitno (2016), dan Atmadja \& Saputra (2017). Hipotesis kedua yang diajukan dalam penelitian ini adalah:

$\mathrm{H}_{2}$ : Sistem pengendalian internal berpengaruh terhadap pencegahan fraud dalam pengelolaan keuangan desa.

\title{
Pengendalian Conflict of Interest
}

Upaya sekelompok masyarakat maupun seseorang untuk memiliki wewenang sehingga terjadi pergesekan pendapat maupun motivasi dapat menimbulkan konflik kepentingan. Menurut Komisi Pemberantasan Korupsi dalam Panduan Penanganan Konflik Kepentingan bagi Penyelenggara Negara, Konflik kepentingan adalah situasi dimana seorang penyelenggara negara yang mendapatkan kekuasaan dan kewenangan berdasarkan peraturan perundang-undangan memiliki atau diduga memiliki kepentingan pribadi atas setiap penggunaan wewenang yang dimilikinya sehingga dapat mempengaruhi kualitas dan kinerja yang seharusnya (KPK, 2009). Jika dikaitkan dengan teori fraud diamond dimana capability (kemampuan) terutama seseorang aparatur desa yang memiliki kewenangan dalam mengelola keuangan desa, menyalahgunakan jabatannya sehingga bertentangan dengan kepentingan masyarakat. Pengendalian conflict of interest sangat penting dalam mengelola keuangan desa, karena adanya conflict of interest menyebabkan munculnya potensi fraud. (Oktaviani et al., 2017).

Menurut teori fraud diamond dan teori agency, dimana capability (kemampuan) terutama seseorang yang memiliki kewenangan dalam mengelola keuangan desa yang dalam hal ini di sebut agent, digunakan untuk kepentingan pribadi sehingga dapat menimbulkan conflict of interest terutama dengan masyarakat yang dalam hal ini sebagai principal. Dengan pengendalian adanya conflict of interest, maka dapat meminimalisir kecurangan dalam pengelolaan keuangan desa. hal ini di dukung oleh penelitian Oktaviani, Herawati, \& Atmadja (2017). Hipotesis ketiga yang diajukan dalam penelitian ini adalah:

$\mathrm{H}_{3}$ : Pengendalian Conflict of interest berpengaruh terhadap pencegahan fraud dalam pengelolaan keuangan desa.

\section{Moralitas}

Aparatur yang bertanggungjawab seharusnya membela kepentingan rakyat dan amanah (Aranta, 2013). Rasionalisasi (Rationalization) adalah fraud terjadi dimana orang membangun pembenaran atas kecurangan yang dilakukan. Dengan moralitas aparatur yang baik maka dapat mencegah kecurangan dalam pengelolaan keuangan desa. Penelitian yang mendukung hal diatas adalah Atmadja dan Saputra (2017) dan Mulia, Febrianto, \& Kartika (2017). Hipotesis keempat yang diajukan dalam penelitian ini adalah:

$\mathrm{H}_{4}$ : Moralitas berpengaruh terhadap pencegahan fraud dalam pengelolaan keuangan desa.

\begin{abstract}
Akuntabilitas
Dalam konteks organisasi sektor publik Mardiasmo (2018) pemerintah daerah (agent) sebagai pelaku pemerintahan harus bertanggungjawab terhadap apa yang telah dilakukannya terhadap masyarakat (principal) dalam rangka menjalankan tugas, wewenang, dan kewajiban Pemerintah Daerah (Oktaviani et al., 2017). Pressure/insentive dalam fraud diamond theory merupakan tekanan/dorongan seseorang untuk berbuat kecurangan baik disebabkan oleh tekanan keuangan/financial maupun tekanan pekerjaan, dengan akuntabilitas keuangan yang baik, dapat mencegah kecurangan dalam pengelolaan keuangan desa. Hal tersebut sesuai dengan penelitian yang dilakukan oleh Saputra, Pradnyanitasari, Priliandani (2019), Fatmawati, Handajani, \& Putra Buana Sakti (2018). Hipotesis kelima yang diajukan dalam penelitian ini adalah:
\end{abstract}


$\mathrm{H}_{5}$ : Akuntabilitas berpengaruh terhadap pencegahan fraud pengelolaan keuangan desa.

\section{Penegakan Hukum}

Proses penegakan hukum merupakan upaya aparatur penegakan hukum tertentu untuk menjamin dan memastikan bahwa suatu aturan hukum berjalan sebagaimana seharusnya. Penegakan hukum yang baik diharapkan dapat mengurangi fraud disektor pemerintahan. Peluang (Opportunity) adalah peluang terjadinya fraud akibat kelemahan didalam sistem penegakan hukum dimana seorang karyawan mempunyai kuasa atau kemampuan untuk memanfaatkan kelemahan tersebut sehingga perbuatan curang dapat dilakukan. Dalam penelitian Najahningrum (2013), Wulandari \& Suryandari (2016) dan Chandra \& Ikhsan (2016) menunjukkan terdapat pengaruh negatif penegakan hukum terhadap kecenderungan kecurangan. Sehingga dengan penerapan penegakan hukum yang baik dapat mencegah terjadinya fraud. Hipotesis keenam yang diajukan dalam penelitian ini adalah:

$\mathrm{H}_{6}$ : Penegakan Hukum berpengaruh terhadap pencegahan fraud pengelolaan keuangan desa.

\section{Kesesuaian Kompensasi}

Kompensasi merupakan balas jasa berupa uang atau barang yang diberikan kepada pegawai atas jasa yang diberikan kepada perusahaan. Pemberian kompensasi sesuai dengan pekerjaan yang dilakukan oleh pegawai diharapkan membuat pegawai merasa tercukupi sehingga akan meningkatkan kinerja pegawai dan mengurangi tindakan kecurangan (fraud) (Adi et al., 2016). Teori Fraud Diamond, dimana pressure/insentive merupakan tekanan/dorongan seseorang untuk berbuat kecurangan baik disebabkan oleh tekanan keuangan/financial maupun tekanan pekerjaan, dengan kesesuaian kompensasi yang memadai dapat mencegah kecurangan dalam pengelolaan keuangan desa. Penelitian yang dilakukan Chandra \& Ikhsan (2015) pada Dinas Pemerintah Kabupaten Grobogan dengan variabel kesesuaian kompensasi, menunjukkan terdapat pengaruh negatif kesesuaian kompensasi terhadap kecenderungan kecurangan akuntansi di sektor pemerintahan. Hipotesis ketujuh yang diajukan dalam penelitian ini adalah:

$\mathrm{H}_{7}$ : Kesesuaian Kompensasi berpengaruh terhadap pencegahan fraud pengelolaan keuangan desa.

\section{METODE PENELITIAN}

\section{Populasi dan Sampel}

Penelitian ini termasuk jenis penelitian kuantitatif dengan sumber data yang digunakan adalah data primer. Populasi dalam penelitian ini adalah seluruh pemerintahan desa di Kabupaten Banjar sebanyak 277 desa, menggunakan rumus Slovin, sehingga jumlah sampel menjadi 164 desa, dimana masing-masing desa diambil 3 responden yang mengelola dana desa yaitu kepala desa, sekretaris desa dan kaur keuangan, sehingga jumlah responden yang digunakan menjadi 492 responden.Teknik pengambilan sampel dalam penelitian ini dengan teknik Probability Sampling.

Pada penelitian ini sebanyak 492 kuesioner yang tersebar, sementara kuesioner yang dikirim kembali sebanyak 472 buah dan yang memenuhi syarat untuk diuji dan dianalisis adalah 448 buah kuesioner $(91,06 \%)$ yang bisa diolah.

Tabel 2.

Tingkat Pengembalian kuesioner

\begin{tabular}{lcc}
\hline \multicolumn{1}{c}{ Keterangan } & Jumlah & Presentase \\
\hline Kuesioner yang disebar & 492 & $100 \%$ \\
\hline Kuesioner yang tidak kembali & 20 & $4,07 \%$ \\
\hline Kuesioner yang kembali & 472 & $95,93 \%$ \\
\hline
\end{tabular}


DETERMINAN FRAUD PREVENTION PADA PEMERINTAHAN DESA DI KABUPATEN BANJAR

Elva Rahmawati, Sarwani, Rasidah, dan Mellani Yuliastina

\begin{tabular}{lcc}
\hline \multicolumn{1}{c}{ Keterangan } & Jumlah & Presentase \\
\hline Kuesioner yang tidak memenuhi syarat & 24 & $4,87 \%$ \\
\hline Kuesioner yang memenuhi syarat & 448 & $91,06 \%$ \\
\hline Sumber : Data diolah , 2019 & &
\end{tabular}

\section{Definisi Operasional dan Pengukuran}

Variabel pada penelitian ini menggunakan tujuh variabel yaitu, pencegahan fraud sebagai variabel dependen. Kompetensi aparatur, sistem pengendalian internal, pengendalian conflict of interest, moralitas, akuntabilitas, penegakan hukum, dan kesesuaian kompensasi sebagai variabel independen. Berikut ini merupakan definisi operasional dan pengukuran dari masing-masing variabel:

Tabel 3.

Indikator variabel Penelitian

\begin{tabular}{|c|c|c|c|c|}
\hline No & Variabel & $\begin{array}{c}\text { Definisi Operasional } \\
\text { Variabel }\end{array}$ & Indikator & $\begin{array}{c}\text { Butir } \\
\text { Pertanyaan }\end{array}$ \\
\hline 1 & $\begin{array}{l}\text { Kompetensi aparatur } \\
\text { adalah (Aruan, } 2003 \\
\text { dalam (M. Ali Fikri } \\
\text { Biana Adha Inapty, } \\
\text { 2016). }\end{array}$ & $\begin{array}{l}\text { Kemampuan yang harus } \\
\text { dimiliki seseorang aparatur } \\
\text { berupa landasan } \\
\text { kepribadian, kemampuan } \\
\text { berkarya, pengetahuan dan } \\
\text { ketrampilan, sikap dan } \\
\text { prilaku serta pemahaman } \\
\text { kaidah kehidupan } \\
\text { bermasyarakat yang } \\
\text { diperlukan dalam } \\
\text { pelaksanaan tugasnya. }\end{array}$ & 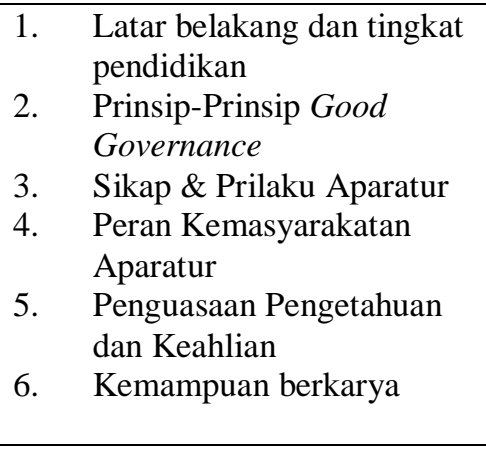 & 10 butir \\
\hline 2 & $\begin{array}{l}\text { Sistem pengendalian } \\
\text { intern pemerintah. } \\
\text { Menurut PP No } 60 \\
\text { tahun } 2008 \text { dan } \\
\text { Inapty \& } \\
\text { Martiningsih (2016) }\end{array}$ & $\begin{array}{l}\text { Sistem pengendalian } \\
\text { internal adalah proses yang } \\
\text { integral pada tindakan dan } \\
\text { kegiatan yang dilakukan } \\
\text { secara terus menerus oleh } \\
\text { pimpinan dan seluruh } \\
\text { pegawai untuk } \\
\text { memberikan keyakinan } \\
\text { memadai atas tercapainya } \\
\text { tujuan organisasi }\end{array}$ & $\begin{array}{ll}\text { 1. } & \text { Lingkungan pengendalian } \\
\text { 2. } & \text { Penaksiran risiko } \\
\text { 3. } & \text { Standar Pengendalian } \\
\text { 4. } & \text { Informasi dan komunikasi } \\
\text { 5. } & \text { Pemantauan }\end{array}$ & 9 butir \\
\hline 3 & $\begin{array}{l}\text { Conflict of interest } \\
\text { Lubhis dan Ishak } \\
\text { (2005) dalam } \\
\text { (Septiningrum, 2016) }\end{array}$ & $\begin{array}{l}\text { Konflik yang terjadi ketika } \\
\text { individu atau organisasi } \\
\text { yang terlibat dalam } \\
\text { berbagai kepentingan }\end{array}$ & $\begin{array}{ll}\text { 1. } & \text { Kekuasaan dan wewenang } \\
\text { 2. } & \text { Kerangkapan jabatan } \\
\text { 3. } & \text { Gratifikasi } \\
\text { 4. } & \text { Kelemahan sistem } \\
& \text { organisasi } \\
\text { 5. } & \text { Kepentingan pribadi } \\
\end{array}$ & 10 butir \\
\hline 4 & $\begin{array}{l}\text { Moralitas, (Aranta, } \\
\text { 2013) }\end{array}$ & $\begin{array}{l}\text { Moralitas yang mengacu } \\
\text { pada nilai-nilai } \\
\text { pribadi atau budaya, kode } \\
\text { etik atau adat istiadat sosial } \\
\text { yang membedakan antara } \\
\text { benar dan salah, sehingga } \\
\text { moralitas pada seorang } \\
\text { aparat sangat berperan } \\
\text { penting sebagai pemegang } \\
\text { komitmen } \\
\text { penyelenggaraan } \\
\text { pemerintahan dan } \\
\text { pembangunan sesuai }\end{array}$ & $\begin{array}{ll}\text { 1. } & \begin{array}{l}\text { Penalaran moral didasarkan } \\
\text { atas imbalan (hadiah) dan } \\
\text { kepentingan sendiri }\end{array} \\
\text { 2. } & \begin{array}{l}\text { Berbuat baik agar } \\
\text { diperlakukan baik oleh }\end{array} \\
\text { lingkungannya. } \\
\text { 3. }\end{array}$ & 6 butir \\
\hline
\end{tabular}




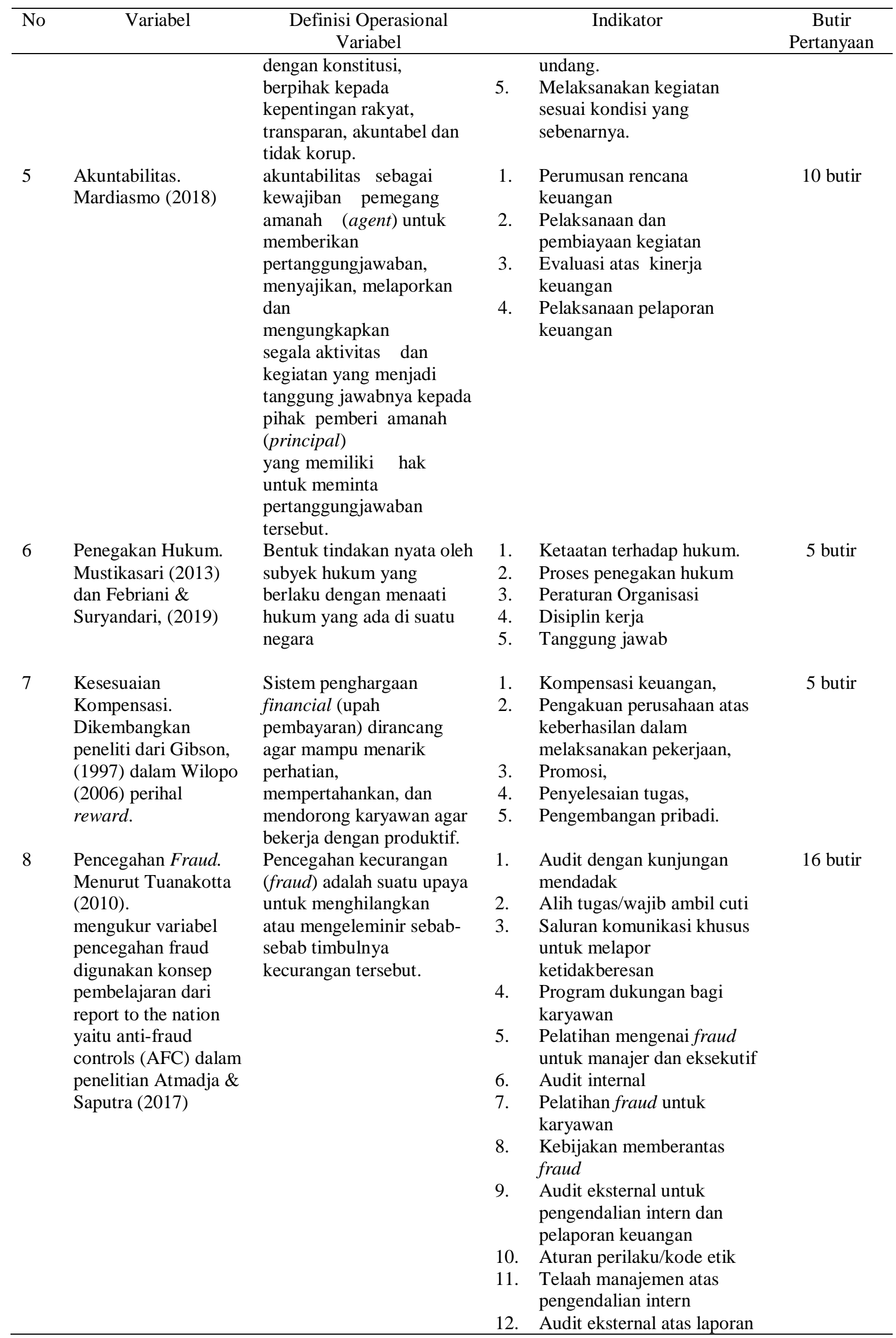




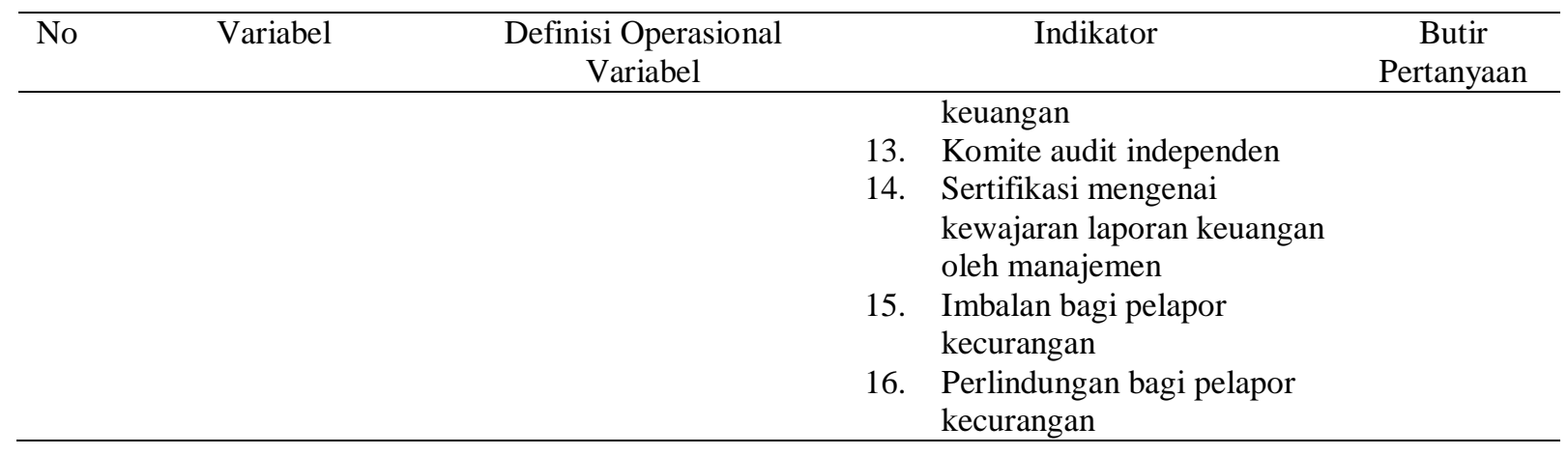

\section{Analisis Data}

Metode analisis yang digunakan adalah regresi linier berganda. Dalam penelitian ini juga digunakan uji asumsi klasik yaitu uji multikolinearitas, uji heteroskedastisitas, dan uji normalitas, selain itu uji hipotesis ( analisis regresi linear berganda, uji t dan uji koefisien determinasi).Untuk mengolah data, peneliti menggunakan bantuan dari aplikasi Microsoft Excel dan program Statistical Package for Social Science (SPSS) 23.

\section{HASIL DAN PEMBAHASAN}

\section{Deskripsi Objek Penelitian}

Penelitian ini menggunakan populasi seluruh desa di Kabupaten Banjar Kalimantan Selatan, dengan jumlah sampel 164 desa yang tersebar merata di 20 kecamatan, sehingga jumlah responden menjadi 492 orang. Sebanyak 492 kuesioner yang tersebar, kuesioner yang dikirim kembali sebanyak 472 buah dan yang memenuhi syarat untuk diolah lebih lanjut adalah 448 buah kuesioner $(91,06 \%)$.

\section{Karakteristik Responden}

Data demografi responden dalam penelitian ini dikelompokkan berdasarkan jabatan, jenis kelamin, usia, pendidikan dan masa kerja. Distribusi responden yang meliputi jumlah dan persentase dari masing-masing responden dapat dilihat dalam tabel berikut:

Tabel 4.

Demografi Responden

\begin{tabular}{llll}
\hline & Karakteristik & Jumlah & Persentase (\%) \\
\hline Jabatan & Kepala Desa & 151 & $33,70 \%$ \\
& Sekretaris Desa & 149 & $33,26 \%$ \\
& Kaur Keuangan & 148 & $33,04 \%$ \\
\hline Jenis Kelamin & Laki-Laki & 448 & $100 \%$ \\
& Wanita & 322 & $71,88 \%$ \\
& & 126 & $28,12 \%$ \\
\hline Usia & $\leq 20$ tahun & 448 & $100 \%$ \\
& 21 s.d 30 tahun & 12 & $26,78 \%$ \\
& 31 s.d 40 tahun & 189 & $42,18 \%$ \\
& 41 s.d 50 tahun & 91 & $19,31 \%$ \\
& 51 s.d 60 tahun & 67 & $14,95 \%$ \\
\hline
\end{tabular}




\begin{tabular}{llll}
\hline Pendidikan & S2 & 5 & $1,12 \%$ \\
& S1 & 120 & $26,79 \%$ \\
& D3 & 17 & $3,78 \%$ \\
& SMA/Sederajat & 255 & $56,91 \%$ \\
& SMP/Sederajat & 51 & $11,38 \%$ \\
\hline Masa Kerja & & 448 & $100 \%$ \\
\hline & 1 s.d 2 tahun & 219 & $48,88 \%$ \\
& 3 s.d 4 Tahun & 107 & $23,89 \%$ \\
& 5 s.d 6 tahun & 122 & $27,23 \%$ \\
\hline
\end{tabular}

Sumber : Data Diolah (2019)

Pada tabel 4 dapat dilihat bahwa karakteristik dari 448 responden berdasarkan jabatan terdiri dari kepala desa 33,70\%, sekretaris desa 33,26\% dan kaur keuangan 33,04\%. Berdasarkan jenis kelamin menunjukkan bahwa persentase responden didominasi oleh jenis kelamin laki-laki yaitu sebanyak $71,88 \%$, sedangkan perempuan hanya $28,12 \%$.

Jumlah responden menurut usia dibedakan menjadi 5 katagori yaitu pada usia $\leq 20$ tahun sebesar $26,78 \%$, sebagian besar aparatur desa berada pada usia 21 s.d 30 tahun yaitu sebanyak 42,18\%, usia 31 s.d 40 tahun sebesar 20,31\%, usia 41 s.d 50 tahun sebanyak $19,86 \%$ dan pada usia 51 s.d 60 tahun sebanyak 14,95\%. Sebagian besar aparatur desa ternyata berada pada usia 21 s.d 30 tahun yaitu sebanyak 189 respoden $(42,18 \%)$, dimana pada usia tersebut merupakan masa produktif untuk bekerja.

Selanjutnya diklasifikasikan berdasarkan tingkat pendidikan S2 sebanyak 1,12\%, S1 sebanyak 26,79\%, D3 sebanyak 3,78\%, SMA/Sederajat sebanyak 56,91\% dan SMP/Sederajat sebanyak 11,38\%. Sedangkan sebagian besar responden dengan masa kerja 1 s.d 2 tahun sebanyak 48,88\%, masa kerja 3 s.d 4 tahun sebanyak 23,89\% dan masa kerja 5 s.d 6 tahun sebanyak $27,23 \%$. Dari data tersebut sebagian besar tingkat pendidikan aparatur desa adalah SMA/Sederajat sebanyak 255 responden dan di dominasi oleh aparatur desa yang memiliki masa kerja 1 s.d 2 tahun yaitu sebanyak 219 responden, dikarenakan banyak Kepala Desa yang habis masa jabatannya sekitar tahun 2017 maupun tahun 2018, sehingga banyak desa yang melakukan penjaringan aparatur desa yang baru.

\section{Statistik Deskriptif}

Statistik deskriptif dapat memberikan gambaran yang sangat bermanfaat dalam melakukan analisis permasalahan. Hasil uji deskriptif dapat dilihat pada tabel 4 sebagai berikut:

Tabel 5

Statistik Deskriptif

\begin{tabular}{lccccc}
\hline & $\mathrm{N}$ & Minimum & Maksimum & Mean & Std.Deviasi \\
\hline Kompetensi Aparatur & 448 & 14 & 50 & 34,63 & 5,396 \\
Sistem Pengendalian & 448 & 19 & 45 & 37,42 & 3,524 \\
$\begin{array}{l}\text { Internal } \\
\text { Pengendalian Conflict of }\end{array}$ & 448 & 10 & 50 & 41,85 & 6,529 \\
Interest & & & & & \\
Moralitas & 448 & 8 & 30 & 23,14 & 3,140 \\
Akuntabilitas & 448 & 18 & 50 & 42,54 & 4,081 \\
Penegakan Hukum & 448 & 11 & 25 & 20,15 & 2,051 \\
Kesesuaian Kompensasi & 448 & 11 & 25 & 19,86 & 1,960 \\
Pencegahan Fraud & 448 & 44 & 80 & 64,75 & 5,556 \\
Valid N (Listwise) & 448 & & & &
\end{tabular}

Sumber : Data diolah (2019) 
Tabel 6

Distribusi Kategori Variabel

\begin{tabular}{|c|c|c|c|}
\hline Variabel & No & Interval & Kategori \\
\hline \multirow[t]{5}{*}{ Kompetensi Aparatur } & 1 & $8,6-16,8$ & Sangat tidak kompeten \\
\hline & 2 & $16,9-25,1$ & Tidak kompeten \\
\hline & 3 & $25,2-33,4$ & Cukup kompeten \\
\hline & 4 & $33,5-41,7$ & Kompeten \\
\hline & 5 & $41,8-50$ & Sangat kompeten \\
\hline \multirow[t]{5}{*}{ Sistem Pengendalian Internal } & 1 & $7,6-15$ & Sangat tidak Efektif \\
\hline & 2 & $15,1-22,5$ & Tidak Efektif \\
\hline & 3 & $22,6-30$ & Cukup Efektif \\
\hline & 4 & $30,1-37,5$ & Efektif \\
\hline & 5 & $37,6-45$ & Sangat Efektif \\
\hline \multirow{5}{*}{$\begin{array}{c}\text { Pengendalian Conflict of } \\
\text { Interest }\end{array}$} & 1 & $8,6-16,8$ & Sangat tidak bisa dikendalikan \\
\hline & 2 & $16,9-25,1$ & tidak bisa dikendalikan \\
\hline & 3 & $25,2-33,4$ & cukup bisa dikendalikan \\
\hline & 4 & $33,5-41,7$ & Bisa dikendalikan \\
\hline & 5 & $41,8-50$ & Sangat bisa di dikendalikan \\
\hline \multirow[t]{5}{*}{ Moralitas } & 1 & $1-6$ & Sangat tidak baik \\
\hline & 2 & $7-12$ & Tidak baik \\
\hline & 3 & $13-18$ & Cukup baik \\
\hline & 4 & $19-24$ & Baik \\
\hline & 5 & $25-30$ & Sangat baik \\
\hline \multirow[t]{5}{*}{ Akuntabilitas } & 1 & $8,6-16,8$ & Sangat tidak akuntabel \\
\hline & 2 & $16,9-25,1$ & tidak akuntabel \\
\hline & 3 & $25,2-33,4$ & cukup akuntabel \\
\hline & 4 & $33,5-41,7$ & akuntabel \\
\hline & 5 & $41,8-50$ & Sangat akuntabel \\
\hline \multirow[t]{5}{*}{ Penegakan Hukum } & 1 & $3,6-7,8$ & Sangat tidak efektif \\
\hline & 2 & $7,9-12,1$ & tidak efektif \\
\hline & 3 & $12,2-16,4$ & Cukup efektif \\
\hline & 4 & $16,5-20,7$ & efektif \\
\hline & 5 & $20,8-25$ & Sangat efektif \\
\hline \multirow[t]{5}{*}{ Kesesuaian Kompensasi } & 1 & $3,6-7,8$ & Sangat tidak sesuai \\
\hline & 2 & $7,9-12,1$ & tidak sesuai \\
\hline & 3 & $12,2-16,4$ & Cukup \\
\hline & 4 & $16,5-20,7$ & sesuai \\
\hline & 5 & $20,8-25$ & Sangat sesuai \\
\hline \multirow[t]{5}{*}{ Pencegahan Fraud } & 1 & $13-26$ & Sangat tidak bisa dicegah \\
\hline & 2 & $27-40$ & Tidak bisa dicegah \\
\hline & 3 & $39-52$ & Cukup bisa dicegah \\
\hline & 4 & $53-66$ & Bisa dicegah \\
\hline & 5 & $67-80$ & Sangat bisa dicegah \\
\hline
\end{tabular}


Berdasarkan tabel 5 di atas, dapat dilihat bahwa nilai standar deviasi kompetensi aparatur 5,396. Artinya, nilai sampel dominan berkumpul di sekitar nilai rata-rata hitungnya sebesar 34,63. Dari hasil tersebut kemudian disesuaikan dengan tabel 6 kategori kompetensi aparatur. Sehingga dapat dikatakan bahwa kompetensi aparatur pada sektor pemerintahan desa di Kabupaten Banjar dalam kondisi kompeten.

Nilai standar deviasi sistem pengendalian internal 3,524. Artinya, nilai sampel dominan berkumpul di sekitar nilai rata-rata hitungnya sebesar 37,42. Dari hasil tersebut kemudian disesuaikan dengan tabel 6 kategori sistem pengendalian internal. Sehingga dapat dikatakan bahwa sistem pengendalian internal pada sektor pemerintahan desa di Kabupaten Banjar dalam kondisi atau kategori efektif. Nilai standar deviasi pengendalian Conflict of Interest 6,529. Artinya, nilai sampel dominan berkumpul di sekitar nilai rata-rata hitungnya sebesar 41,85. Dari hasil tersebut kemudian disesuaikan dengan tabel 6 kategori pengendalian Conflict of Interest. Sehingga dapat dikatakan bahwa pengendalian Conflict of Interest pada sektor pemerintahan desa di Kabupaten Banjar dalam kondisi atau kategori sangat bisa dikendalikan.

Nilai standar deviasi moralitas 3,140. Artinya, nilai sampel dominan berkumpul di sekitar nilai rata-rata hitungnya sebesar 23,14. Dari hasil tersebut kemudian disesuaikan dengan tabel 6 kategori moralitas. Sehingga dapat dikatakan bahwa moralitas pada sektor pemerintahan desa di Kabupaten Banjar dalam kondisi atau kategori baik. Nilai standar deviasi akuntabilitas 4,081. Artinya, nilai sampel dominan berkumpul di sekitar nilai rata-rata hitungnya sebesar 42,54. Dari hasil tersebut kemudian disesuaikan dengan tabel 6 kategori akuntabilitas. Sehingga dapat dikatakan bahwa akuntabilitas pada sektor pemerintahan desa di Kabupaten Banjar dalam kondisi atau kategori sangat akuntabel.

Nilai standar deviasi penegakan hukum 2,051. Artinya, nilai sampel dominan berkumpul di sekitar nilai rata-rata hitungnya sebesar 20,15. Dari hasil tersebut kemudian disesuaikan dengan tabel 6 kategori penegakan hukum. Sehingga dapat dikatakan bahwa penegakan hukum pada sektor pemerintahan desa di Kabupaten Banjar dalam kondisi atau kategori efektif. Nilai standar deviasi kesesuaian kompensasi 1,960. Artinya, nilai sampel dominan berkumpul di sekitar nilai rata-rata hitungnya sebesar 19,86. Dari hasil tersebut kemudian disesuaikan dengan tabel 6 kategori kesesuaian kompensasi. Sehingga dapat dikatakan bahwa kesesuaian kompensasi pada sektor pemerintahan desa di Kabupaten Banjar dalam kondisi atau kategori sesuai.

Nilai standar deviasi pencegahan fraud 5,556. Artinya, nilai sampel dominan berkumpul di sekitar nilai rata-rata hitungnya sebesar 64,75. Dari hasil tersebut kemudian disesuaikan dengan tabel 6 kategori pencegahan fraud. Sehingga dapat dikatakan bahwa pencegahan fraud pada sektor pemerintahan desa di Kabupaten Banjar dalam kondisi atau kategori bisa dicegah.

Hasil pengujian validitas dan reliabilitas instrumen menunjukkan bahwa instrumen yang digunakan dalam penelitian ini adalah valid dan reliabel. Validitas dalam penelitian ini ditunjukkan dengan nilai koefisien korelasi item total variabel lebih besar dari 0,3 dan signifikansi lebih kecil dari 0,05, sedangkan reliabilitas ditunjukkan dengan nilai cronbach alpha untuk semua variabel lebih besar dari 0,70. 
Tabel 7

Hasil Uji Reliabilitas

\begin{tabular}{lcl}
\hline \multicolumn{1}{c}{ Variabel } & Cronbach Alpha & Product \\
\hline Kompensasi Aparatur $\left(\mathrm{X}_{1}\right)$ & 0,873 & Reliabel \\
Sistem Pengendalian Intern $\left(\mathrm{X}_{2}\right)$ & 0,862 & Reliabel \\
Pengendalian Conflict of Interest $\left(\mathrm{X}_{3}\right)$ & 0,940 & Reliabel \\
Moralitas $\left(\mathrm{X}_{4}\right)$ & 0,797 & Reliabel \\
Akuntabilitas $\left(\mathrm{X}_{5}\right)$ & 0,895 & Reliabel \\
Penegakan Hukum $\left(\mathrm{X}_{6}\right)$ & 0,751 & Reliabel \\
Kesesuaian Kompensasi $\left(\mathrm{X}_{7}\right)$ & 0,721 & Reliabel \\
Pencegahan Fraud $(\mathrm{Y})$ & 0,877 & Reliabel \\
\hline
\end{tabular}

Sumber : Data diolah (2019)

Uji normalitas dengan Kolmogorov Smirnov menunjukkan Asymp.Sig sebesar 0,138 > 0,05 menunjukkan bahwa data variabel adalah berdistribusi normal, karena memiliki nilai lebih besar dari taraf signifikan 0,05.

Tabel 8

Uji Normalitas

\begin{tabular}{lcc}
\hline One-Sample Kolmogorov-Smirnov Test & Unstandardized \\
& & Residual \\
N & 448 \\
Normal Parameters & Mean & $-0,1011357$ \\
& Std. & 2,99947164 \\
Most Extreme & Deviation & \\
Differences & Absolute & 0,055 \\
& Positive & 0,055 \\
Kolmogorov-Smirnov Z & Negative & $-0,030$ \\
Asymp. Sig. (2-tailed) & & 1,156 \\
Test distribution is Normal. & & 0,138 \\
Calculated from data. & & \\
\hline Sumber : Data diolah (2019) & &
\end{tabular}

Pengujian Multikolinearitas memberikan hasil nilai VIF kurang dari 10 yaitu berkisar 1,152 - 1,974, sehingga tidak terdapat gejala multikolinearitas.

Tabel 9

Uji Multikolinearitas

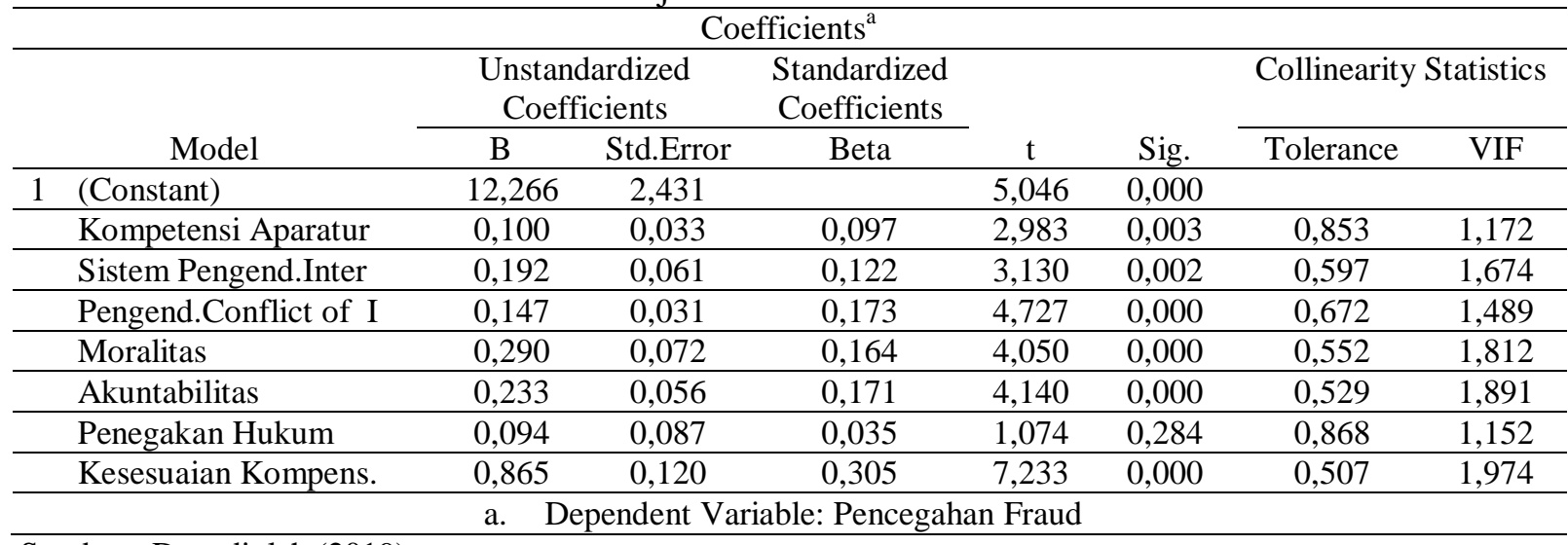

Sumber : Data diolah (2019)

Uji Heteroskedastisitas dengan uji spearman's rho menunjukkan bahwa masing-masing variabel memiliki nilai signifikan yang lebih besar 0,05 sehingga dapat dinyatakan bahwa tidak terdapat gejala heteroskedastisitas, sehingga penelitian dapat dilanjutkan. 
Tabel 10

Uji Heteroskedastisitas Menggunakan Spearman Rho

\begin{tabular}{lcl}
\hline \multicolumn{1}{c}{ Variabel } & Sign & Keterangan \\
\hline Kompetensi Aparatur $\left(\mathrm{X}_{1}\right)$ & 0,148 & Tidak Terdapat Gejala Heteroskedastisitas \\
Sistem Pengendalian Intern $\left(\mathrm{X}_{2}\right)$ & 0,810 & Tidak Terdapat Gejala Heteroskedastisitas \\
Pengendalian Conflict of Interest $\left(\mathrm{X}_{3}\right)$ & 0,425 & Tidak Terdapat Gejala Heteroskedastisitas \\
Moralitas $\left(\mathrm{X}_{4}\right)$ & 0,603 & Tidak Terdapat Gejala Heteroskedastisitas \\
Akuntabilitas $\left(\mathrm{X}_{5}\right)$ & 0,988 & Tidak Terdapat Gejala Heteroskedastisitas \\
Penegakan Hukum $\left(\mathrm{X}_{6}\right)$ & 0,109 & Tidak Terdapat Gejala Heteroskedastisitas \\
Kesesuaian Kompensasi $\left(\mathrm{X}_{7}\right)$ & 0.666 & Tidak Terdapat Gejala Heteroskedastisitas \\
\hline Sumber Data diolah $(2019)$ & &
\end{tabular}

Untuk mengetahui pengaruh variabel bebas secara parsial terhadap pencegahan fraud (Y) adalah dengan menggunakan uji t pada Level of Confidence sebesar 95\% atau $\alpha=5 \%$. Nilai t bila memiliki probabilitas masing-masing faktor tersebut lebih kecil dari tingkat alpha $(\alpha)=0,05$ maka dinyatakan bahwa variabel bebas tersebut berpengaruh signifikan terhadap pencegahan fraud $(\mathrm{Y})$. Adapun nilai t tabel berdasarkan $(\mathrm{df})=(\mathrm{n}-1-\mathrm{k})$ adalah sebesar 1,965, dimana df adalah derajat bebas dan $\mathrm{k}$ adalah banyaknya variabel. Jadi nilai t tabel dihitung pada nilai $\mathrm{df}=(448-1-7)=440$.

Tabel 11

Hasil Uji t - Statistik

\begin{tabular}{|c|c|c|c|c|c|}
\hline \multicolumn{6}{|c|}{ Coefficients $^{a}$} \\
\hline \multirow[b]{2}{*}{ Model } & \multicolumn{2}{|c|}{$\begin{array}{l}\text { Unstandardized } \\
\text { Coefficients }\end{array}$} & \multirow{2}{*}{$\begin{array}{c}\begin{array}{c}\text { Standardized } \\
\text { Coefficients }\end{array} \\
\text { Beta } \\
\end{array}$} & \multirow[b]{2}{*}{$\mathrm{t}$} & \multirow[b]{2}{*}{ Sig. } \\
\hline & B & Std.Error & & & \\
\hline $\begin{array}{ll}1 & \text { (Constant) }\end{array}$ & 12,266 & 2,431 & & 5,046 & 0,000 \\
\hline Kompetensi Aparatur & 0,100 & 0,033 & 0,097 & 2,983 & 0,003 \\
\hline $\begin{array}{l}\text { Sistem Pengendalian } \\
\text { Internal }\end{array}$ & 0,192 & 0,061 & 0,122 & 3,130 & 0,002 \\
\hline $\begin{array}{l}\text { Pengend. Conflict of } \\
\text { Interest }\end{array}$ & 0,147 & 0,031 & 0,173 & 4,727 & 0,000 \\
\hline Moralitas & 0,290 & 0,072 & 0,164 & 4,050 & 0,000 \\
\hline Akuntabilitas & 0,233 & 0,056 & 0,171 & 4,140 & 0,000 \\
\hline Penegakan Hukum & 0,094 & 0,087 & 0,035 & 1,074 & 0,284 \\
\hline Kesesuaian Kompensasi & 0,865 & 0,120 & 0,305 & 7,233 & 0,000 \\
\hline Dependent Variable: Pe & $\operatorname{lan}$ Frauc & & & & \\
\hline
\end{tabular}

Sumber: Data diolah (2019)

Berdasarkan tabel diatas semua variabel memiliki nilai $t_{\text {hitung }}$ yang lebih besar dari nilai $\mathrm{t}_{\text {tabel }}$ dan nilai signifikan yang lebih kecil dari taraf signifikan atau $<0,05$. Namun ada satu variabel yang berbeda yaitu penegakan hukum dimana nilai thitung sebesar 1,074 dan tingkat signifikan sebesar 0,284. Hal tersebut menunjukkan bahwa variabel Penegakan Hukum (X6) tidak berpengaruh signifikan terhadap pencegahan fraud $(\mathrm{Y})$. Pembuktian Dari pernyataan

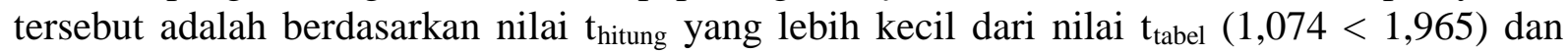
nilai signifikan yang lebih besar dari taraf signifikan $(0,284>0,05)$.

Hasil pengujian hipotesis untuk koefisien determinasi $\left(\mathrm{R}^{2}\right)$ dapat dilihat pada tabel 11 sebagai berikut: 
Tabel 12

Hasil Uji Koefisien Determinasi $\left(\mathrm{R}^{2}\right)$

\begin{tabular}{ccccc}
\hline & \multicolumn{4}{c}{ Model Summary } \\
\hline Model & $\mathrm{R}$ & $\mathrm{R}$ Square & $\begin{array}{c}\text { Adjusted R } \\
\text { Square }\end{array}$ & Std. Error of the Estimate \\
\hline 1 & $0,777^{\mathrm{a}}$ & 0,603 & 0,597 & 3,528 \\
\hline
\end{tabular}

Predictors: (constant), Kompetensi Aparatur, Sistem Pengendalian Internal, Pengendalian Conflict of Interest, Moralitas, Akuntabilitas, Penegakan Hukum, Kesesuaian Kompensasi.

Sumber: Data Diolah (2019)

Hasil Uji Determinasi diperoleh nilai $\mathrm{R}$ dengan sebesar 0,777 atau 77,7\% menunjukkan tingkat hubungan yang tinggi antara variabel dependen dan independen karena berada di antara 0,600 sampai dengan 0,799 . Nilai $R_{\text {Square }}$ dengan nilai 0,603 adalah $R^{2}$, yang menunjukkan bahwa variabel independen yang diambil dalam penelitian ini mampu menjelaskan variabel dependen sebesar 60,3\% sehingga selebihnya sebesar 39,7\% adalah dijelaskan oleh variabel-variabel lain yang tidak dikemukakan dalam penelitian ini. Adjusted $\mathrm{R}$ Square mempunyai nilai sebesar 0,597 yang menunjukkan bahwa variasi atau naikturunnya variabel dependen (Y) dipengaruhi oleh variabel independen (X) sebesar 59,7\%. Standard Error of the Estimate (SEE) diperoleh sebesar 3,528. Nilai ini lebih kecil dari standar deviasi variabel pencegahan fraud yaitu 5,556 sehingga model regresi layak digunakan.

Hasil uji regresi linear berganda berdasarkan data hasil penelitian dan output program SPSS 23 sebagai berikut:

Tabel 13

Hasil Pengolahan Data Regresi Linear Berganda

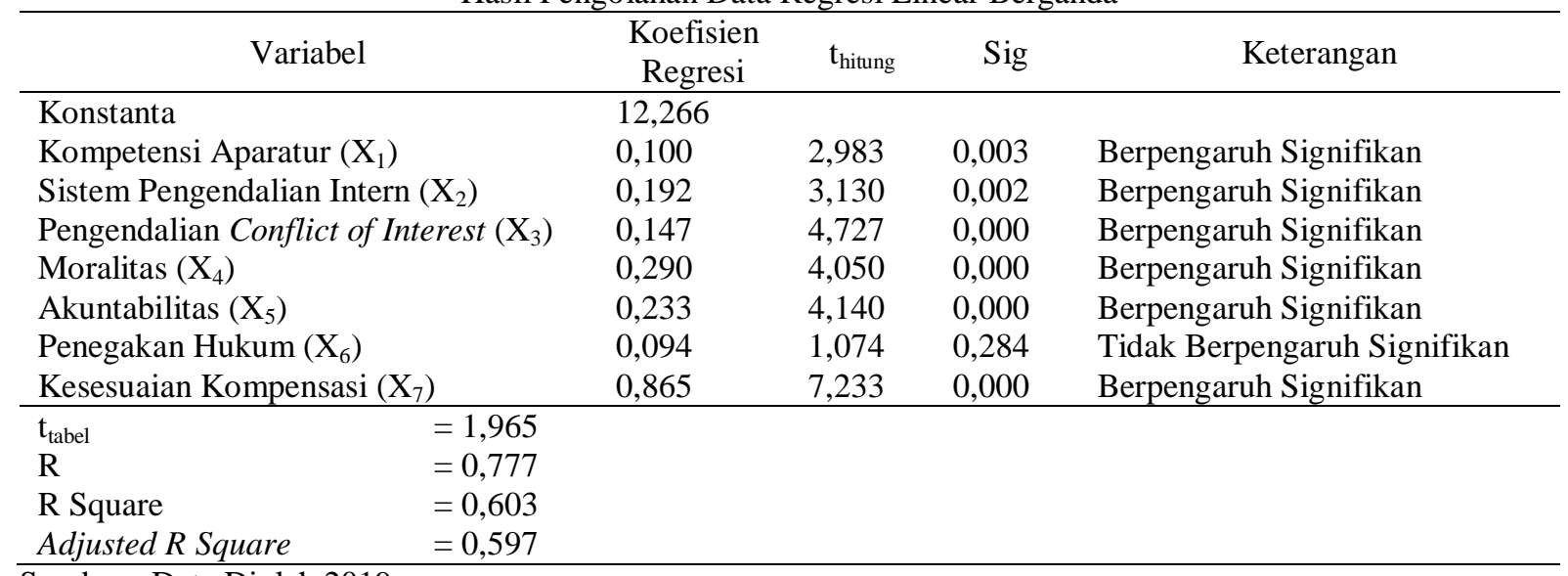

Sumber : Data Diolah 2019

Berdasarkan hasil uji regresi linear berganda pada tabel 13, menunjukkan bahwa Kompensasi Aparatur (X1) berpengaruh signifikan terhadap Pencegahan Fraud (Y), dimana nilai thitung yang lebih besar dari nilai ttabel $(2,983>1,965)$ dan nilai signifikan yang lebih kecil dari taraf signifikan $(0,003<0,05)$, serta nilai koefisien regresi sebesar 0,100 . Sistem pengendalian internal (X2) berpengaruh signifikan terhadap Pencegahan Fraud (Y), dimana nilai thitung yang lebih besar dari nilai ttabel $(3,130>1,965)$ dan nilai signifikan yang lebih kecil dari taraf signifikan $(0,002<0,05)$, serta nilai koefisien regresi sebesar 0,192 . Pengendalian conflict of interest (X3) berpengaruh signifikan terhadap Pencegahan Fraud $(Y)$, dimana nilai thitung yang lebih besar dari nilai ttabel $(4,727>1,965)$ dan nilai signifikan yang lebih kecil dari taraf signifikan $(0,000<0,05)$, serta nilai koefisien regresi sebesar 0,147 .

Moralitas (X4) berpengaruh signifikan terhadap Pencegahan Fraud (Y), dimana nilai thitung yang lebih besar dari nilai ttabel $(4,050>1,965)$ dan nilai signifikan yang lebih kecil dari taraf signifikan $(0,000<0,05)$, serta nilai koefisien regresi sebesar 0,290 . Akuntabilitas 
(X5) berpengaruh signifikan terhadap Pencegahan Fraud (Y), dimana nilai thitung yang lebih besar dari nilai ttabel $(4,140>1,965)$ dan nilai signifikan yang lebih kecil dari taraf signifikan $(0,000<0,05)$, serta nilai koefisien regresi sebesar 0,233. Penegakan hukum (X6) tidak berpengaruh signifikan terhadap Pencegahan Fraud (Y), dimana nilai thitung yang lebih kecil dari nilai ttabel $(1,074<1,965)$ dan nilai signifikan yang lebih besar dari taraf signifikan $(0,284>0,05)$, serta nilai koefisien regresi sebesar 0,094. Kesesuaian kompensasi (X7) berpengaruh signifikan terhadap Pencegahan Fraud (Y), dimana nilai thitung yang lebih besar dari nilai ttabel $(7,233>1,965)$ dan nilai signifikan yang lebih kecil dari taraf signifikan $(0,000<0,05)$, serta nilai koefisien regresi sebesar 0,865 .

\section{Pengaruh Kompetensi Aparatur Terhadap Pencegahan Fraud.}

Berdasarkan hasil uji regresi linear berganda menunjukkan bahwa Kompetensi Aparatur (X1) berpengaruh signifikan terhadap Pencegahan Fraud (Y). Hal ini dapat dijelaskan bahwa peningkatan kompetensi aparatur desa dapat mencegah kecurangan dalam pengelolaan keuangan desa. Jika dilihat dari hasil statistik deskriptif, nilai standar deviasi kompetensi aparatur cenderung tinggi (5,396), yang menunjukkan adanya perbedaan kualitas dari aparat desa baik dari sisi tingkat pendidikan maupun pengetahuan tentang ilmu akuntansi serta cara mengoperasionalkan siskeudes. Hasil demografi responden dalam tabel 4 terlihat sebanyak $255(56,91 \%)$ responden berpendidikan SMA, 120 (26,79\%) responden berpendidikan S1 yang tidak semuanya jurusan ekonomi. Hal ini tentunya sangat berpengaruh terhadap tingkat kompetensi aparatur desa yang belum merata.

Variabel Kompetensi aparatur diukur dengan 5 indikator, dari jawaban responden diketahui bahwa terdapat 3 indikator dimana yang rentang jawabannya tidak merata yaitu pada indikator latar belakang dan tingkat pendidikan, pemahaman prinsip good governance (transparansi, integritas dan akuntabilitas) serta indikator penguasaan pengetahuan dan keahlian ( ilmu akuntansi dan keahlian mengoperasionalkan siskeudes). Jika aparatur desa tidak memahami prinsip good governance, kurangnya pemahaman akuntansi serta tingkat pendidikan yang rendah, hal ini tentunya membuka peluang besar untuk terjadinya kecurangan dalam mengelola keuangan desa.

Menurut teori Fraud Diamond, dimana opportunity (peluang) dan capability (kapasitas) adalah kelemahan dalam sistem yang dapat dimanfaatkan berbuat fraud, baik kelemahan pengendalian internalnya maupun kelemahan dalam hal kompetensi aparaturnya. Namun dengan kompetensi aparatur bila dikaitkan dengan capability bisa menjadi dua mata pisau., bisa menjadi pencegah segala tindak kecurangan dapat di cegah, atau malah pengantar untuk melakukan fraud. Pencegah apabila aparatur paham akan konsekunsinya yang diterima apabila melakukan fraud atau pengantar apabila aparatur sudah tidak peduli dengan konsekunsi dan memilih egois untuk melakukan fraud.

Untuk itu implikasi hasil penelitian ini adalah pelatihan keuangan desa sebaiknya diadakan per kecamatan dengan jumlah instruktur pendamping yang memadai sehingga materi dapat di serap dan lebih efektif dalam menyelesaikan permasalahan yang dialami aparatur desa. Keberadaan pendamping desa dan pendamping lokal desa yang berkualitas sangat diperlukan karena dapat memberikan arahan dan solusi atas permasalahan yang sering dialami di lapangan. Diadakan sertifikasi oleh kementrian dalam negeri terhadap kepala desa serta aparatur desa dengan pelatihan pengelolaan keuangan dana desa yang nantinya menjadi standar minimal kompetensi bahwa desa tersebut layak untuk menerima bantuan dana desa.

\section{Pengaruh Sistem Pengendalian Internal Terhadap Pencegahan Fraud Dalam Pengelolaan Keuangan Desa.}

Berdasarkan hasil uji regresi linear berganda menunjukkan bahwa sistem pengendalian internal (X2) berpengaruh signifikan terhadap Pencegahan Fraud (Y). Hal ini dapat 
dijelaskan bahwa peningkatan sistem pengendalian internal dapat mencegah kecurangan dalam pengelolaan keuangan desa.. Laporan keuangan yang reliable sangat di pengaruhi oleh pengendalian internal yang efektif, dan hal ini seharusnya berlaku untuk semua tahapan dalam pengelolaan keuangan desa. Hasil penelitian ini konsisten dengan Mulia, Febrianto, \& Kartika (2017), Zulaikha \& Hadiprajitno (2016), dan Atmadja \& Saputra (2017) yang menyatakan bahwa pengendalian internal memiliki pengaruh yang signifikan terhadap pencegahan fraud.

Menurut Teori keagenan di mana sistem pengendalian internal diperlukan untuk mengawasi perilaku agen (aparat atau perangkat desa) dan menurut Teori Fraud Diamond dimana Opportunity (peluang) adalah kelemahan dalam sistem yang dapat dimanfaatkan berbuat fraud dalam merealisasikan laporan keuangan desa. Laporan realisasi keuangan yang akuntabel, ketaatan peraturan, efisiensi operasional dapat terlaksana dengan pengendalian internal yang efisien (Kummer et al., 2015). Kualitas pengendalian yang baik dapat meminimalkan perilaku mengutamakan kepentingan pribadi (opportunistic) yang ingin dilakukan oleh para aparat desa(Wijayanti \& Hanafi, 2018). Implikasi hasil penelitian ini adalah Pemerintah Daerah maupun Kecamatan membuat pemetaan terhadap semua permasalahan yang ditemukan di lapangan, agar prioritas penyelesaian masalah dapat terlaksana dengan efektif.

\section{Pengaruh Pengendalian Conflict of Interest Terhadap Pencegahan Fraud Pengelolaan Keuangan Desa}

Berdasarkan hasil uji regresi linear berganda menunjukkan bahwa pengendalian conflict of interest (X3) berpengaruh signifikan terhadap Pencegahan Fraud (Y). Hal ini dapat dijelaskan bahwa pengendalian conflict of interest dapat mencegah kecurangan dalam pengelolaan keuangan desa. Hasil penelitian ini sesuai dengan teori Fraud Diamond, dimana Capability (kemampuan), yaitu kekuasaan seseorang yang menjabat jika digunakan untuk kepentingan pribadi, maka akan menimbulkan penyelewengan, tentunya hal ini mengurangi kinerjanya (Oktaviani et al., 2017). Sementara itu dalam teori agensi dimana manusia pada umumnya mementingkan diri sendiri (self interest), khususnya yang memiliki kewenangan terhadap pengelolaan dana desa, sehingga dapat menimbulkan konflik kepentingan. Penelitian Oktaviani, herawati, \& Atmadja (2017) memberi hasil bahwa pengendalian terhadap konflik kepentingan merupakan hal yang sangat penting untuk meminimalisir adanya kecurangan.

Implikasi hasil penelitian ini adalah regulasi mengenai kewajiban pemerintah desa untuk mempublikasikan keuangan desa memang sudah tertuang dalam Permendagri No 20 Tahun 2018 pasal 39, namun pelaksanaan dilapangan perlu di tegakkan lagi. Pemerintah Daerah mewajibkan agar seluruh anggaran pendapatan dan belanja desa di publikasikan ke masyarakat melalui papan pengumuman di setiap RW, dengan ini masyarakat dapat ikut berpartisipasi dan melakukan pengawasan dalam pengelolaan dana desa sehingga tidak ada kesalahpahaman antara masyarakat dan pihak aparatur desa(Peraturan Menteri Dalam Negeri No 20 Tahun 2018 Tentang Pengelolaan Keuangan Desa, 2018).

\section{Pengaruh Moralitas Terhadap Pencegahan Fraud Pengelolaan Keuangan Desa}

Berdasarkan hasil uji regresi linear berganda menunjukkan bahwa Moralitas (X4) berpengaruh signifikan terhadap Pencegahan Fraud (Y). Hal ini dapat dijelaskan bahwa peningkatan moralitas aparatur desa dapat mencegah kecurangan dalam pengelolaan keuangan desa. Rendahnya kualitas moral yang ditandai dengan ketidakjujuran dan sikap tidak peduli apabila terjadi penyelewengan aparatur desa dapat menyuburkan korupsi yang pada akhirnya dapat merusak organisasi (Amrizal, 2004). Tolok ukur atas perilaku seseorang secara akal sehat dan sesuai dengan lubuk hati didasari oleh moralitas seseorang (Berger et al., 2017). 
Hasil penelitian ini jika dikaitkan dengan teori agensi, termasuk dalam asumsi self interest, umumnya mementingkan diri sendiri, hal ini dapat dicegah melalui peningkatan moral karena manajemen adalah kumpulan individu yang memiliki tahapan moral dengan tanggung jawab sosial. selain itu jika dikaitkan teori Fraud Diamond, dimana Rasionalisasi (Rationalization) terjadi karena pertimbangan perilaku kecurangan sebagai konsekuensi dari kesenjangan integritas pribadi karyawan. Dengan moralitas aparatur yang baik maka dapat mencegah kecurangan dalam pengelolaan keuangan desa. Implikasi hasil penelitian dapat dilakukan dengan melaksanakan sosialisasi tentang fraud dan sanksi yang akan di terima bagi pelanggarnya. Selain itu pimpinan menerapkan moralitas yang baik kepada para staf, dengan memberi contoh yang baik, menjunjung tinggi kejujuran dan mencintai pekerjaan. Jika moralitas terjaga dengan baik, maka kecurangan pun dapat dihindari

Penelitian Rahimah, Murni, \& Lysandra(2018), Atmadja dan Saputra (2017), Aranta (2013) dan Wilopo (2006), yang meyatakan bahwa moralitas berpengaruh signifikan terhadap pencegahan kecurangan akuntansi, artinya adalah bahwa semakin tinggi moralitas aparatur yang dimiliki pegawai maka kecendrungan kecurangan akuntansi yang dilakukan oleh pemerintah juga akan semakin menurun.

\section{Pengaruh Akuntabilitas Terhadap Pencegahan Fraud Pengelolaan Keuangan Desa.}

Hasil uji regresi linear berganda menunjukkan bahwa akuntabilitas $\left(\mathrm{X}_{5}\right)$ berpengaruh signifikan terhadap Pencegahan Fraud (Y). Hal ini dapat dijelaskan bahwa peningkatan akuntabilitas dapat mencegah kecurangan dalam pengelolaan keuangan desa. Akuntabilitas sangat berkaitan dengan teori agensi, dimana kewajiban agent yang dalam hal ini adalah pemerintahan desa untuk mempertanggungjawabkan penggunaan dana desa kepada principal yaitu masyarakat. Dengan akuntabilitas yang baik maka laporan keuangan dana desa dapat dipertanggungjawabkan secara akuntabel dan transparan sehingga dapat mencegah kecurangan dalam pengelolaan keuangan desa. Dalam teori Fraud Diamond, dimana pressure/insentive, merupakan tekanan keuangan/financial maupun tekanan pekerjaan, namun dengan bekerja secara profesional dapat menghasilkan praktek akuntabilitas keuangan yang baik, sehingga dapat mencegah kecurangan dalam pengelolaan keuangan desa.

Hasil penelitian ini sejalan dengan Oktaviani, Herawati, \& Atmadja (2017) dan Saputra, Pradnyanitasari, Priliandani (2019) yang menyatakan bahwa akuntabilitas memiliki pengaruh yang positif terhadap pencegahan fraud pengelolaan dana desa. Implikasi hasil penelitian bahwa perlu dibangun kepercayaan masyarakat terhadap pemerintah dengan jalan melaksanakan prinsip responsif terhadap kebutuhan atau usulan masyarakat dan merealisasikannya dalam bentuk kegiatan pembangunan desa. Pembinaan pengelolaan dana desa mengenai penyusunan laporan keuangan, pemahaman mengenai mekanisme, teknik sistem akuntansi serta standar akuntansi pemerintahan.

\section{Pengaruh Penegakan Hukum Terhadap Pencegahan Fraud Pengelolaan Keuangan Desa.}

Berdasarkan hasil uji regresi linear berganda menunjukkan bahwa penegakan hukum (X6) Tidak berpengaruh signifikan terhadap Pencegahan Fraud (Y). Hal ini dapat dijelaskan bahwa peningkatan penegakan hukum tidak dapat mencegah kecurangan dalam pengelolaan keuangan desa. Jika dilihat dari jawaban kuesioner, variabel penegakan hukum memiliki 5 indikator, yang memiliki rata-rata jawaban terendah yaitu 3,91 adalah pada indikator proses penegakan hukum, lebih jelasnya pada pertanyaan soal no.2 yaitu " Di instansi tempat saya bekerja, saya merasa para pejabat tanggap dalam penanganan pelanggaran peraturan". Artinya ketika ditemukan suatu pelanggaran pada instansi tempat responden bekerja, maka pejabat yang dalam hal ini yaitu pimpinan/kepala desa kurang tanggap dan cenderung membiarkan, sehingga kurang peduli dengan pelanggaran peraturan yang terjadi. Hal ini terjadi karena 
longgarnya pengawasan penggunaan dana desa yang dilakukan oleh aparat pengawas, dimana dalam satu tahun hanya dua desa dalam satu kecamatan yang mendapat giliran untuk di periksa. Tentunya dapat berakibat desa yang belum mendapat giliran pemeriksaan cenderung untuk meremehkan peraturan yang ada.

Para pejabat instansi pemerintahan desa masih mengabaikan peraturan hukum yang berlaku sehingga para pejabat instansi tersebut masih leluasa untuk melakukan tindak kecurangan (fraud). Selain itu, pemberian sanksi yang diberikan kepada para pelanggar masih kurang tegas sehingga tidak menimbulkan efek jera kepada para pelaku kecurangan (fraud). Faktor lainnya yaitu longgarnya pengawasan penggunaan dana desa yang dilakukan oleh aparat pengawas, dimana dalam satu tahun hanya dua desa dalam satu kecamatan yang mendapat giliran untuk di periksa. Tentunya dapat berakibat desa yang belum mendapat giliran pemeriksaan cenderung untuk meremehkan peraturan yang ada.

Permendagri No 20 Tahun 2018 dalam pasal 7 disebutkan bahwa kaur dan kasi selaku PPKD ( Pelaksana Pengelola Keuangan Desa) dibantu oleh tim yang melaksanakan kegiatan pengadaan barang/jasa yang karena sifat dan jenisnya tidak dapat dilakukan sendiri. Adapun yang bisa menjadi tim tersebut adalah unsur perangkat desa, Lembaga Kemasyarakatan Desa dan/atau masyarakat(Peraturan Menteri Dalam Negeri No 20 Tahun 2018 Tentang Pengelolaan Keuangan Desa, 2018). Dalam hal pemilihan tim ini dapat menimbulkan kurangnya transparansi terutama dari unsur masyarakat. Dalam regulasi yang ada tidak dijelaskan masyarakat yang seperti apa, sehingga yang sering terjadi masih ada hubungan kerabat dengan kepala desa yang tentunya hal ini berpotensi adanya kecurangan dalam hal pengadaan barang/jasa.

Menurut fraud diamond theory, peluang (opportunity) yaitu apabila penegakan hukum/peraturan di suatu instansi lemah, maka akan membuka peluang bagi pegawai untuk melakukan kecurangan, dan sebaliknya. Hasil penelitian yang sejalan dengan penelitian ini adalah Oktaviani, Herawati, \& Atmadja (2017), Sari (2016), Zulqarnain (2013) yang menyatakan bahwa penegakan hukum berpengaruh positif terhadap potensi fraud, semakin tinggi penegakan hukum maka tidak dapat mengurangi potensi fraud. Namun berbeda dengan hasil penelitian Chandra \& Ikhsan (2015) dan penelitian Wulandari \& Suryandari (2016) dimana menyatakan bahwa terdapat pengaruh negatif antara penegakan hukum dengan kecenderungan kecurangan di sektor pemerintahan, artinya semakin baik hukum dan aturan ditegakkan dan ditaati maka kecenderungan kecurangan di sektor pemerintahan akan menurun, hal ini sesuai dengan teori agensi dimana pihak principal melakukan pengawasan atas kinerja agent, agar tidak melanggar aturan dan cenderung berbuat curang.

Hasil penelitian ini menunjukkan bahwa penegakan hukum tidak mampu mempengaruhi pencegahan fraud, hal ini di sebabkan bahwa kebanyakan masyarakat mengerti tentang hukum akan tetapi tidak mematuhinya. Dasar hukum mengenai pelarangan tindakan fraud baik berupa undang-undang maupun peraturan daerah bagi pegawai maupun pejabat pemerintahan, dan dasar hukum mengenai sanksi bagi pelaku fraud baik berupa penjara maupun denda uang, sudah banyak diterapkan sebagai dasar pengelolaan keuangan desa, namun masih banyak kasus yang terjadi, hal ini mengindikasikan bahwa hukum seperti tidak memiliki kekuatan bagi pelaku fraud(Oktaviani et al., 2017).

\section{Pengaruh Kesesuaian Kompensasi Terhadap Pencegahan Fraud Pengelolaan Keuangan Desa.}

Berdasarkan hasil uji regresi linear berganda menunjukkan bahwa Kesesuaian Kompensasi berpengaruh signifikan terhadap Pencegahan Fraud (Y). Hal ini dapat dijelaskan bahwa peningkatan kesesuaian kompensasi desa dapat mencegah kecurangan dalam pengelolaan keuangan desa. Sistem kompensasi adalah sistem penghargaan financial (upah pembayaran) dirancang agar mampu menarik perhatian, mempertahankan, dan mendorong 
karyawan agar bekerja dengan produktif, Sistem kompensasi yang sesuai diharapkan dapat membuat individu merasa tercukupi sehingga individu tidak melakukan tindakan yang merugikan organisasi termasuk melakukan tindakan kecurangan akuntansi (fraud)(Chandra \& Ikhsan, 2015).

Menurut teori Fraud Diamond, dimana pressure/insentive merupakan tekanan keuangan/financial maupun tekanan pekerjaan yang menyebabkan seseorang berbuat kecurangan, dengan kesesuaian kompensasi yang memadai dapat mencegah kecurangan dalam pengelolaan keuangan desa. Hasil penelitian ini konsisten dengan Chandra \& Ikhsan (2015), Zulqarnain (2013) yang menyatakan bahwa kesesuaian kompensasi berpengaruh negatif terhadap kecenderungan kecurangan akuntansi (fraud). Namun berbeda dengan hasil penelitian Adinda \& Ikhsan (2015), Adi, Ardiyani, \& Ardianingsih (2016) dan Wilopo (2006) yang menyatakan bahwa tidak terdapat pengaruh antara kesesuaian kompensasi dengan kecenderungan kecurangan, dimana pemberian kompensasi belum tentu dapat menekan kecurangan dalam suatu organisasi.

Implikasi hasil penelitian bahwa kesesuaian kompensasi dapat membuat aparatur desa merasa tercukupi sehingga tidak melakukan tindakan kecurangan akuntansi (fraud). Sementara itu kompensasi yang diterima aparatur masih minim di bawah stándar Upah Minimum Kabupaten, hal ini belum sesuai dengan UU ketenagakerjaan. Untuk itu pemerintah daerah dapat menaikkan kompensasi aparatur desa minimal sesuai dengan Upah Minimum Kabupaten, hal ini mengingat dana desa yang dikelola dalam jumlah besar.

\section{PENUTUP}

Simpulan yang dapat diambil dari penelitian ini bahwa kompetensi aparatur, sistem pengendalian internal, pengendalian conflict of interest, moralitas, akuntabilitas, dan kesesuaian kompensasi berpengaruh terhadap pencegahan fraud dalam pengelolaan keuangan desa. Sedangkan penegakan hukum tidak berpengaruh terhadap pencegahan fraud dalam pengelolaan keuangan desa.Tujuan utama dana desa yaitu untuk kesejahteraan masyarakat, hal ini dapat terwujud salah satunya dengan pengelolaan keuangan desa secara professional yang dilaksanakan oleh aparatur desa dengan kemampuan yang memadai, yang nantinya akan diawasi dan bersentuhan langsung dengan BPK yang independen.

Penelitian ini diharapkan dapat memberikan kontribusi bagi pihak yang berkepentingan untuk dapat mengupayakan pencegahan kecurangan yaitu dengan memperbaiki sistem dan mekanisme pengawasan dana desa, mengoptimalkan monitoring tindak lanjut hasil pemeriksaan di desa, pihak Pemerintah Daerah dan Kecamatan menggunakan hasil pemeriksaan dari pihak aparatur pengawas sebagai bahan pembinaan dan pengawasan untuk mendorong desa melakukan perbaikan, transparansi dalam rekrutmen atau penjaringan aparat desa, reformasi birokrasi terutama di sektor penegakan hukum dan peradilan.

Pemerintah daerah beserta pengawas melakukan pemetaan fokus (identifikasi) permasalahan dalam pengelolaan DD dan ADD sebagai dasar untuk penetapan prioritas pengawasan, bila perlu data kasus tersebut di umumkan ke masyarakat agar aparatur desa memiliki efek jera dan lebih berhati-hati dalam mengelola dana desa.

Pemerintah menyediakan program pelaporan dan perlindungan whistleblower secara online di level desa maupun kecamatan, atas penggunaan dana desa yang dirasa tidak sesuai dengan penggunaannya. Selanjutnya dapat dilakukan assessment lapangan dan cross check terhadap laporan tersebut, bila benar dapat di lanjutkan ke aparatur pengawas yang pada akhirnya melakukan audit lanjutan hingga mengeluarkan rekomendasi selanjutnya untuk proses hukum.

Untuk penelitian selanjutnya disarankan untuk menguji kembali variabel penegakan hukum, dipertimbangkan dengan menggunakan instrument yang lain. Bagi peneliti 
selanjutnya agar menambah jumlah sampel dan wilayah penelitian menjadi tingkat propinsi, serta menambah variabel penelitian lain terkait pencegahan fraud misalnya locus of control, budaya organisasi, sistem informasi akuntansi serta pedoman atau standar akuntansi.

Announcement :

Paper ini telah dipresentasikan pada kegiatan Festival Ekonomi Islam-Fakultas Ekonomi dan Bisnis Islam, UIN Walisongo Semarang, pada tanggal 24 September 2019

\section{DAFTAR PUSTAKA}

Adi, Ardiyani, \& Ardianingsih. (2016). Analisis Faktor-Faktor Penentu Kecurangan (Fraud) Pada Sekotr Pemerintahan:Studi Kasus Pada Dinas Pendapatan Pengelolaan Keuangan dan Aset Daerah Kota Pekalongan. Jurnal Litbang Kota Pekalongan, 10, 1-10. http://jurnal.pekalongankota.go.id/index.php/litbang/article/viewFile/39/37

Adi, K., Saputra, K., Pradnyanitasari, P. D., Made, N., Priliandani, I., Gst, I., \& Putra, N. P. (2019). Praktek Akuntabilitas dan Kompetensi Sumber Daya Manusia Untuk Pencegahan Fraud Dalam Pengelolaan Dana Desa. 10(2), 168-176.

Adinda, Y. M., \& Ikhsan, S. (2015). Faktor Yang Mempengaruhi Terjadinya Kecurangan (Fraud) Di Sektor Pemerintahan Kabupaten Klaten. Accounting Analysis Journal, 1(2), 1-6. https://doi.org/ISSN 2252-6765

Amrizal. (2004). Pencegahan Dan Pendeteksian Kecurangan. Http://Bpkp.Go.Id/. http://bpkp.go.id/public/upload/unit/investigasi/files/Gambar/PDF/cegah_deteksi.pdf

Aranta. (2013). Pengaruh Moralitas Aparat dan Asimetri Informsi terhadap Kecenderungan Kecurangan Akuntansi.

Atmadja, A. T., Adi, K., \& Saputra, K. (2017). Pencegahan Fraud Keuangan Desa. 1, 7-16. Badan Pemeriksa Keuangan. (2018). Laporan Hasil Pemeriksaan.

Berger, L., Perreault, S., \& Wainberg, J. (2017). Hijacking the moral imperative: How financial incentives can discourage whistleblower reporting. Auditing. https://doi.org/10.2308/ajpt-51663

Chandra, D. P. (Universitas N. S., \& Ikhsan, S. (Universitas N. S. (2015). Determinan Terjadinya Kecenderungan Kecurangan Akuntansi (Fraud) Pada Dinas Pemerintah seKabupaten Grobogan. Accounting Analysis Journal, 3(1), 361-369. https://doi.org/ISSN 2252-6765

Donelson, D. C., Ege, M. S., \& McInnis, J. M. (2017). Internal Control Weaknesses and Financial Reporting Fraud. AUDITING: A Journal of Practice \& Theory, 3(36), 45-69.

Eisenhardt, K. M. (1989). Agency Theory: An Assessment and Review. Academy of Management Review. https://doi.org/10.5465/amr.1989.4279003 
Fatmawati, A., Handajani, L., Putra, D., \& Sakti, B. (2018). Village Funds Accountability and Misuse Prevention. 1(36), 45-55.

Febriani, F., \& Suryandari, D. (2019). Analisis Faktor-Faktor Yang Berpengaruh Terhadap Kecenderungan Kecurangan (Fraud): Persepsi Pegawai Pada Dinas Kota Tegal. Jurnal Kuntansi, 9(1), 33-46. https://doi.org/Https://doi.org/10.33369/j.akuntansi.9.1.33-46

Harry Krishna Mulia, M., Febrianto, R., \& Kartika, R. (2017). Pengaruh Moralitas Individu dan Pengendalian Internal terhadap Kecurangan: Sebuah Studi Eksperimental. Jurnal Akuntansi Dan Investasi, 18(2), 198-208. https://doi.org/10.18196/jai.180283

Inayatillah, H. I. A. dan D. A. (2015). Persepsi Aparatur Fungsional Tentang Keahlian Dan Sistem Pengendalian Intern Pemerintah terhadap Pencegahan Kecurangan ( (Studi Pada Kantor Inspektorat Daerah Kabupaten Konawe). Jurnal Akunransi Dan Keuangan Fakultas Ekonomi Dan Bisnis, Universitas Halu Oleo, 13-15.

Indonesia Corruption Watch. (2018). Outlook Dana Desa.

Jensen, M. C., \& Meckling, W. H. (1976). Theory of the Firm: Managerial. Journal of Financial Economics. https://doi.org/http://dx.doi.org/10.1016/0304-405X(76)90026-X

KPK. (2009). Panduan Penanganan Konflik Kepentingan Bagi Penyelenggara Negara. Komisi Pemberantasan Korupsi. www.kpk.go.id

Kummer, T. F., Singh, K., \& Best, P. (2015). The effectiveness of fraud detection instruments in not-for-profit organizations. Managerial Auditing Journal, 30(4-5), 435-455. https://doi.org/10.1108/MAJ-08-2014-1083

Mardiasmo. (2018). Akuntansi Sektor Publik: Edisi Terbaru. Penerbit Andi.

Mustikasari, D. P. (2013). FAKTOR-FAKTOR YANG MEMPENGARUHI FRAUD DI SEKTOR PEMERINTAHAN KABUPATEN BATANG. Accounting Analysis Journal, 2(3). https://doi.org/10.15294/aaj.v2i3.2492

Najahningrum, A. F. (2013). Faktor-Faktor yang Mempengaruhi Fraud: Persepsi Pegawai Dinas Provinsi DIY. Accounting Analysis Journal, 2(3), 259-267.

Oktaviani, I. A. A., Nyoman, T. H., \& Atmadja, A. T. (2017). Pengaruh Praktik Akuntabilitas , Conflict Of Interest Dan Penegakan Hukum Terhadap Potensi Fraud Dalam Pengelolaan Keuangan Desa Di Kabupaten Buleleng. E-Journal Universitas Pendidikan Ganesha, 8(2), 1-10.

Undang Undang Republik Indonesia No 6 Tahun 2014 Tentang Desa, (2014). http://www.dpr.go.id/doksileg/proses2/RJ2-20171106-094054-7086.pdf

Peraturan Menteri Dalam Negeri No 20 Tahun 2018 Tentang Pengelolaan Keuangan Desa, (2018).

Priantara, D. (2013). Fraud Auditing \& Investigation (1st ed.). Mitra Wacana Media. 
Rahimah, L. N., Murni, Y., \& Lysandra, S. (2018). Pengaruh Penyajian Laporan Keuangan Desa, Lingkungan Pengendalian dan Moralitas Individu Terhadap Pencegahan Fraud Yang Terjadi Dalam Pengelolaan Alokasi Dana Desa. Jurnal Ilmiah Ilmu Ekonomi.

Sari, D. (2016). Terjadinya Fraud Pada Sektor Pemerintahan Kota Bandar Lampung: Persepsi Pegawai Pemerintahan. Universitas Lampung.

Siahaya; Asnawi; Layuk, E. M. P. (2015). Pengaruh Kompetensi Sumber Daya Manusia, Sistem Pengendalian Internal Pemerintah dan Penerapan Sistem Akuntansi Keuangan Daerah Terhadap Kualitas Laporan Keuangan Pemerintah Propinsi Papua. Jurnal Kajian Ekonomi Dan Keuangan Daerah, 1-16.

Tribunnews.com. (2018). Kasus Korupsi Dana Desa Kahelaan Kabupaten Banjar Siap Disidangkan. http://banjarmasin.tribunnews.com/2018/07/16/kasus-korupsi-dana-desakahelaan- kabupaten-banjar-siap-disidangkan, 22 oktober 2018

Tuanakotta, T. M. (2010). Akuntansi Forensik dan Audit Investigasi. Salemba Empat.

Wijayanti, P., \& Hanafi, R. (2018). Pencegahan Fraud Pada pemerintahan desa. Jurnal Akuntansi Multiparadigma, 9(2), 331-345.

Wilopo. (2006). Analisis Faktor-Faktor Yang Berpengaruh Terhadap Kecenderungan Kecurangan Akuntansi: Studi Pada Perusahaan Publik Dan Badan Usaha Milik Negara Di Indonesia. Jurnal Riset Akuntansi Indonesia, 2(031), 12-13. https://doi.org/10.1001/jama.1994.03520170077040

Wolfe, D., \& Dana, H. (2004). The Fraud Diamond: Considering The Four Element of Fraud. The CPA Journal, 12, 38-42.

Wulandari, R. \& D. S. (2016). Faktor-Faktor yang mempengaruhi Fraud pada Satuan Kerja Pemerintah Daerah Kabupaten Temanggung. Accounting Analysis Journal, 5(2), 76-85. http://journal.unnes.ac.id/sju/index.php/aaj

Yamin, Ridha, S. (2015). Faktor Penentu Jumlah Temuan Kelemahan Sistem Pengendalian Intern pada Pemerintah Daerah di Indonesia. 1-24.

Zulaikha, \& Hadiprajitno, P. T. B. (2016). Faktor-Faktor Yang Memengaruhi Procurement Fraud: Sebuah Kajian Dari Perspektif Persepsian Auditor. Jurnal Akunransi Dan Keuangan Indonesia, 13(2), 194-220. 